NBER WORKING PAPER SERIES

\title{
IMPLICATIONS OF MEDICAID FINANCING REFORM FOR STATE GOVERNMENT BUDGETS
}

Jeffrey Clemens

Benedic Ippolito

Working Paper 23965

http://www.nber.org/papers/w23965

\author{
NATIONAL BUREAU OF ECONOMIC RESEARCH \\ 1050 Massachusetts Avenue \\ Cambridge, MA 02138 \\ October 2017
}

We thank Joe Antos, Nicholas Bagley, Alex Brill, Matt Fiedler, John Klemm, Sean Speer, Michael Strain, and the participants of the Harrington Symposium on Health Economics at the University of Texas at Austin for helpful feedback. The views expressed herein are those of the authors and do not necessarily reflect the views of the National Bureau of Economic Research.

NBER working papers are circulated for discussion and comment purposes. They have not been peer-reviewed or been subject to the review by the NBER Board of Directors that accompanies official NBER publications.

(C) 2017 by Jeffrey Clemens and Benedic Ippolito. All rights reserved. Short sections of text, not to exceed two paragraphs, may be quoted without explicit permission provided that full credit, including $\odot$ notice, is given to the source. 
Implications of Medicaid Financing Reform for State Government Budgets

Jeffrey Clemens and Benedic Ippolito

NBER Working Paper No. 23965

October 2017

JEL No. H72,H75,H77

\begin{abstract}
$\underline{\text { ABSTRACT }}$
We analyze potential reforms to Medicaid financing through the lens of fiscal federalism. Because substantial dollars are at stake, both the economic and political sides of intergovernmental transfers have high relevance in this setting. We show that changes in Medicaid financing formulas can shift amounts exceeding several hundred dollars per capita from "winning" states to "losing" states. In some cases, these amounts exceed 10 percent of states' own-source revenues. States' balanced budget requirements imply that such changes would, if not phased in gradually, require significant budgetary adjustment over short time horizons. We next show that alternative Medicaid financing structures have significant implications for states' exposure to budgetary stress during recessions. During the Great Recession, an acyclical block grant structure would have increased states' shortfalls by 2--3.5 percent of own-source revenues relative to either an explicitly countercyclical block grant or the current matching system. Finally, we assess the implications of several financing structures for the extent to which they subsidize states' decisions on both the "extensive" and "intensive" margins of coverage generosity over the short and long term.
\end{abstract}

\author{
Jeffrey Clemens \\ Department of Economics \\ University of California, San Diego \\ 9500 Gilman Drive \#0508 \\ La Jolla, CA 92093 \\ and NBER \\ jeffclemens@ucsd.edu
}

Benedic Ippolito

American Enterprise Institute

1789 Massachusetts Avenue

Washington, DC 20036, USA

benedic.ippolito@aei.org 
While intergovernmental transfers rarely steal headlines, federal contributions to state Medicaid programs are an occasional exception. This reflects the sheer magnitude of federal Medicaid spending and, by extension, its importance for state government budgets. In 2015, federal contributions to state Medicaid programs totaled $\$ 350$ billion. These transfers equaled 2 percent of GDP, roughly one-fifth of state governments' general revenues, and more than half of total federal transfers to the states.

Because Medicaid plays a prominent role in state government finances, Medicaid financing reforms have significant fiscal implications. This paper assesses the implications of alternative Medicaid financing structures along several dimensions. We show that the fine print of financing reform can have first-order implications for the distribution of federal Medicaid spending across states. We thus consider the "distributive politics" of financing reforms in some detail.

Beyond the distributive politics perspective, we consider several issues with roots in the economics of fiscal federalism. One set of issues involves states' incentives regarding both the generosity and management of their Medicaid programs. A second, related issue involves the division of long-run financing responsibilities between states and the federal government. The more quantitative and novel portion of our analysis highlights two important yet underappreciated issues involving the continuity of state government finances.

Medicaid is financed jointly by the federal and state governments. The existing program's basic financing structure involves federal "matching grants." For each dollar a state spends, the federal government provides the state with an amount determined by the applicable match rate. The primary match rate is known as the federal medical assistance percentage (FMAP). This match rate varies in accordance with a formula involving the ratio of a state's per capita income to the national average. Match rates for coverage of traditional Medicaid beneficiaries range from a 
legislated floor of 50 percent for high-income states to a ceiling of 83 percent for lowincome states. ${ }^{1}$ In addition to varying across states, the federal share varies across coverage groups. It is higher for children covered through the State Children's Health Insurance Program and for adults covered through the Medicaid expansion created by the Affordable Care Act than for traditional Medicaid eligibility groups.

Proposals to reform federal Medicaid financing have a long history. The primary reform of interest involves converting Medicaid from its long-standing "matching grant" structure into either a traditional "block grant" or an intermediate "perbeneficiary" allocation structure. As documented by Lambrew (2005) and Park and Broaddus (2011), proposals to convert federal Medicaid contributions into a block grant have appeared in every decade since the $1980 \mathrm{~s}^{2}$

Key features of block grant design vary across proposals. Under traditional block grant proposals, states' allocations would be independent of both their programs' eligibility rules and the generosity of the benefits to which each participant is entitled. The financing reforms included in recent legislative proposals to reform the Affordable Care Act (ACA) can be described as a hybrid between the current matching grant structure and the traditional block grant structure. In this paper we will emphasize the specific proposal included in the American Health Care Act (AHCA), which involves matching payments up to a maximum federal contribution that rises with the number of beneficiaries a state's program covers. ${ }^{3}$ Beyond this maximum contribution, the effective match rate under the AHCA proposal is 0 percent. ${ }^{4}$ The

\footnotetext{
${ }^{1}$ Roughly 10-15 states receive the minimum 50 percent match rate in a given year. In FY 2015 those states were Alaska, California, Connecticut, Maryland, Massachusetts, Minnesota, New Hampshire, New Jersey, New York, North Dakota, Rhode Island, Virginia, Washington, and Wyoming. In practice, the 83 percent maximum on FMAPs is not binding, as matching rates have not risen above 75 percent in recent years (Mississippi typically receives the highest federal match).

${ }^{2}$ Iterations include a 1981 proposal from President Ronald Reagan, a 1995 proposal from Congressman Newt Gingrich, a 2003 proposal from President George W. Bush, and a 2010 proposal from Congressman Paul Ryan and Alice Rivlin of the Brookings Institution.

${ }^{3}$ This financing structure was commonly described as a "per capita cap" despite being neither a cap on state spending nor a per capita allocation.

${ }^{4}$ For a detailed discussion, see Adler, Fiedler, and Gronniger (2017).
} 
key feature of per-beneficiary structures is that they subsidize the generosity of states' coverage rules on extensive margins (i.e., the margins that determine how many individuals are eligible) while eliminating the matching grant's subsidy of coverage on intensive margins (i.e., the margins that determine the amount of spending on care per beneficiary).

The academic literature on intergovernmental transfers highlights a broad set of conceptual issues related to their design. A first set of issues involves the incentives intergovernmental transfers create. The central considerations can be summarized as involving a trade-off between creating incentives to provide public goods and maintaining incentives for states to operate their programs efficiently. That is, match rates can be viewed as subsidies that correct for underinvestment in public goods (BerndSpahn, 2007). At the same time, "optimal" match rates must account for distortions to states' incentives to manage their programs efficiently (Smart, 2007).

A second set of issues involves the distribution of resources across jurisdictions (in the context of education finance, for example, see Hoxby, 2001; Card and Payne, 2002; Jackson, Johnson, and Persico, 2016). Redistribution across jurisdictions can reflect a variety of policy objectives. Relevant "optimal policy" objectives may include a desire to narrow long-run differences in economic capacity or a desire to facilitate short-run recovery from economic shocks (Von Hagen, 2007).

Both the incentive effects and the distributional effects of intergovernmental grants can be analyzed through a political economy lens as well as through an optimal policy lens. Sato (2007) analyzes the straightforward political economy considerations that arise when designing transfers that redistribute across jurisdictions. Boadway and Shah (2007) and Baicker, Clemens, and Singhal (2012) discuss the political economy implications of using intergovernmental transfers as a means for one level of government to encourage or coerce other levels of government into engaging in particular activities. 
Our analysis empirically assesses three features of Medicaid financing reform. We first show that financing reforms have substantive implications for the distribution of federal Medicaid dollars across states. We highlight the dramatic difference between two straightforward alternatives: status-quo block grants and uniform, need-based grants. We first allocate federal funding via "status-quo block" grants that are equal to the federal contributions states received in 2015. We next allocate the same aggregate of federal funding using an alternative formula. Specifically, we consider a "uniform, need-based" block grant determined by variations in per capita income across states.

The funding formulas we consider differ significantly because of variation in the generosity of states' existing programs. This is due in part to states' decisions regarding the ACA's Medicaid expansions; ACA related funding accounts for more than one third of some states' federal Medicaid dollars. Many states' federal Medicaid allocations differ by more than 50 percent across the financing formulas we consider. New York, for example, would receive nearly $\$ 16$ billion less per year under the incomebased block grants we consider compared to the status quo. Texas, by contrast, would receive nearly $\$ 8$ billion more under income-based block grants than under the status quo.

In addition to distributive politics, we highlight two underappreciated issues involving the continuity of state government finances. Budget continuity is relevant because of states' fiscal institutions. Because of their balanced budget requirements, states in which federal Medicaid allocations decline must adjust their finances over relatively short time horizons. ${ }^{5}$ Options include increasing own-source revenues and reducing expenditures. The shifts implied by the alternative allocation rules we consider are sufficiently large that the adjustments required to satisfy states' balanced

\footnotetext{
${ }^{5}$ This is particularly true of states in which balanced budget requirements include a so-called "No Carry" provisions. "No Carry" provisions prevent states from carrying short-term general obligation debt from one fiscal year into the next, which leads in practice to relatively rapid fiscal adjustment in response to unexpected shocks (Poterba, 1994; Clemens and Miran, 2012).
} 
budget requirements would be significant. Fiscal institutions thus provide a rationale for relatively gradual transitions from Medicaid's current financing structure toward any final allocation Congress intends to achieve.

The example of New York illustrates the relevance of federal Medicaid contributions' magnitudes. As noted above, New York would lose nearly $\$ 16$ billion under a purely income-based allocation of federal Medicaid funds. This amounts to 16 percent of New York's own-source general revenues from 2014. Closing such a shortfall through revenue measures would thus require all taxes, user fees, and charges to rise substantially to make up for lost federal contributions.

Fiscal rules are also relevant for states' exposure to the business cycle. Medicaid's current matching grant structure limits this exposure by automatically increasing federal spending as a recession increases the number of individuals who are eligible for, and participating in, the program. Traditional block grants are acyclical and would not have this feature. Consequently, acyclical block grants would increase the extent to which states must engage in contractionary adjustments to satisfy their balanced budget requirements during recessions. We analyze two alternatives to acyclical block grants that would relieve these recessionary fiscal strains.

Reducing states' exposure to the business cycle requires increasing federal contributions during recessions. Block grants could ease cyclical strains if aggregate Medicaid funding is indexed to business cycle conditions. A simple approach, for example, would be to increase the federal government's contribution by some fixed percent per unit change in the national unemployment rate. We illustrate the implications of this approach in the context of the Great Recession. As desired, the adjustment can be calibrated to make federal Medicaid financing more, less, or roughly as countercyclical as the current system. We also analyze a "per-beneficiary allocation" approach that is similar in spirit to the AHCA's proposed changes to Medicaid financing. Because federal allocations rise with a states' number of beneficiaries, this approach is more 
countercyclical than traditional block grants.

A final set of issues involves the long-run division of Medicaid financing responsibilities between the states and the federal government. With block grants, the evolution of this division depends crucially on the rate at which federal contributions are scheduled to grow. Under the AHCA and other recent proposals, the federal share tends to decline over time because the growth rate is set lower than the expected growth rate of per-person medical expenditures. We show that alternative financing structures have quite different long-run implications for states' incentives to cover new beneficiaries. Over the very long run, the division of Medicaid financing between states and the federal government may be viewed as a federal mechanism for maintaining a floor on the generosity of states' Medicaid programs.

The remainder of this paper proceeds as follows. Section 1 briefly describes the data on which we rely. Section 2 defines the financing structures we subsequently analyze. Section 3 illustrates the cross-state distributional implications of alternative funding schemes. Section 4 presents simulations of federal contributions under alternative funding structures during the Great Recession. Section 5 discusses the long-run implications of alternative funding structures. Section 6 considers states' potential responses to changes in the incentives alternative structures entail. Section 7 concludes.

\section{Data Sources}

States' Medicaid expenditures are the primary focus of our analysis. We take data on Medicaid spending from 2006 through 2015 from financial management reports submitted by states on Form CMS-64. The data we use describe total spending in each state, with a division into state and federal contributions. We analyze all 50 states and the District of Columbia, but exclude the U.S. territories. In addition, 
we use state enrollment figures from the Medicaid Analytic eXtract (as of December 2016). All enrollment figures are person-year equivalents. ${ }^{6}$

Our analysis uses data from a number of additional sources. We use data on personal income per capita from the Bureau of Economic Analysis. Our analysis of states' exposure to business cycle fluctuations uses data on state unemployment rates (for the population ages 16 and over) from the Bureau of Labor Statistics. We use Kaiser Family Foundation (KFF) estimates of the number of each state's residents with incomes below the poverty line. These estimates were prepared by KFF using the March 2016 Current Population Survey. Finally, we analyze state budget data from the Annual Survey of State and Local Government Finances, which is also collected by the U.S. Census Bureau. Our analysis of state budgets focuses on own-source revenues, defined as the sum of all revenue raised directly by the state through taxes, fees, and charges.

\section{Defining Alternative Financing Structures}

Our analysis considers three financing structures: status-quo block grants; uniform, need-based grants; and per-beneficiary allotments. While not exhaustive, these options capture the central design features at issue in discussions of alternative Medicaid financing structures. In this section we describe the basic features of each financing structure.

\subsection{Status-Quo Block Grants}

We first consider a block grant based on each state's current federal Medicaid allocations. This financing structure has been included in a number of proposals over recent decades. For example, it was recently included as part of the Medicaid reform

\footnotetext{
${ }^{6}$ We thank John Klemm of the Office of the Actuary at the Centers for Medicare and Medicaid Services for generously providing previously formatted data on enrollment and spending.
} 
proposal in Speaker Paul Ryan's A Better Way. ${ }^{7}$ This design sets each state's baseline block grant equal to its federal allocation from a base year $\bar{t}$, with annual increases at growth rate $g_{t}$. For state $s$ in year $t$, the federal allocation under the status-quo block (SQB) grant is thus

$$
\text { Block Grant }_{s, t}^{S Q B}=\text { Federal Funding } s_{s, \bar{t}} \times \prod_{i=\bar{t}}^{t}\left(1+g_{i}\right) .
$$

Our analysis of the cross-state distributional implications of this funding formula focuses on a baseline of fiscal year 2015. We expand on the cyclical implications of this funding structure in section 4.

\subsection{Uniform, Need-Based Block Grant}

We next analyze a block grant design that divorces federal allocations from current spending levels. Under a uniform, need-based block grant, federal dollars are allocated based on measures of states' need. ${ }^{8}$ This financing system would allocate similar amounts to states in similar economic circumstances, adjusted for population, irrespective of their historical choices regarding the generosity of their Medicaid programs (Helms, 2007).

Our analysis of uniform, need-based grants bases federal allocations on variations in states' per capita personal incomes. We use a measure quite similar to the measure used to determine states' match rates under the current matching grant structure. Doing so helps isolate changes in federal spending due to financing design from those due to alternative measures of state need. ${ }^{9}$ Specifically, the adjustment factor is based

\footnotetext{
${ }^{7}$ See https://abetterway.speaker.gov

${ }^{8}$ Designs of this form have long been advocated by critics of the current funding structure (e.g., Helms, 2007). Recent proposals, including the Healthcare Accessibility, Empowerment, and Liberty Act of 2016, envision a transition from the status-quo structure towards some form of uniform, need-based allocation.

${ }^{9}$ Distributions are changed modestly by using alternative measures of funding need.
} 
on a lagged three-year moving average of state per capita income (PCI): ${ }^{10}$

$$
\text { Income Factor } s, t=\frac{3 \text {-year moving avg } \mathrm{PCI}_{U S, t}}{3 \text {-year moving avg } \mathrm{PCI}_{s, t}}
$$

The allocations we consider allow for the full range of variation in the Income Factor implied by the formula above. This contrasts with the existing FMAP formula, which is constrained to lie between a maximum subsidy rate of 83 percent and minimum subsidy rate of 50 percent. ${ }^{11}$

To simulate a state's federal allocation under the uniform need-based structure, we begin by calculating Income Factor ${ }_{s, t}$. We then multiply this factor by the state's population $\left(\right.$ Pop. $\left._{s, t}\right)$. We then set a global scaling factor such that the sum of federal dollars across states equals actual federal spending from the base year $\bar{t}$. The scaling factor is grown at the legislatively specified rate $g_{t}$. For state $s$ in year $t$, we have:

$$
\text { Block Grant }_{s, t}^{U N B}=\text { Income Factor }_{s, t} \times \text { Pop }_{s, t} \times \text { Scaling Factor }_{\bar{t}} \times \prod_{i=\bar{t}}^{t}\left(1+g_{i}\right)
$$

Our analysis of the cross-state distributional implications of this funding formula again focuses on a baseline of fiscal year 2015.

\section{$2.3 \quad$ Per-Beneficiary Allocations}

Finally, we consider a proposed alternative to block granting - namely, per-beneficiary allocations $(\mathrm{PBA}) .{ }^{12}$ In this financing system the federal government fixes the amounts

\footnotetext{
${ }^{10}$ Matching rates under the current system are: $\mathrm{FMAP}_{s, t}=1-\left(\frac{(3 \text {-year moving avg } \mathrm{PCI})_{s, t}^{2}}{(3 \text {-year moving avg } \mathrm{PCI})_{U . S ., t}^{2}} \cdot 0.45\right)$

${ }^{11}$ Congress' decision to constrain the range of FMAPs may reflect a desire to avoid subsidy rates deemed either too stingy or too generous. This highlights a dimension along which the block grant and matching grant structures differ. In the block grant context, the Income Factor's sole function is to generate redistribution from high-income states to low-income states. In the matching grant context, the Income Factor both generates redistribution and subsidizes program expenditures on the margin.

${ }^{12}$ Speaker Paul Ryan's reform agenda A Better Way, for example, offers states the option to chose between a per-beneficiary allotment and a status-quo block grant. Similarly, the AHCA proposal included a provision to define a state's maximum federal contribution on a per capita basis.
} 
it will reimburse states for each Medicaid enrollee. As such, program enrollment, but not other features of program generosity, would dictate a state's federal funding allocation. As with traditional block grants, program parameters can have significant implications for the initial allocation of federal funds. Funds may be allocated, for example, based on current state spending per beneficiary (e.g., the average amount each state currently spends per beneficiary), on a uniform per-beneficiary basis across states (e.g., the national average per-beneficiary spending), or on a hybrid of these basic approaches.

Our analysis focuses on a variant of PBA in which allocations are based on statespecific estimates of spending per beneficiary. This is the general approach taken in the recent AHCA proposal. Also as in the AHCA proposal, the variant we analyze allows per-beneficiary allocations to vary across eligibility categories. This limits the severity of selection incentives that would arise, for example, if states receive the same allocation for covering a child as for covering a disabled adult. The AHCA differs in that the per-beneficiary amount dictates the maximum amount the federal government will contribute, rather than an explicit allotment. In practice, it is likely that the AHCA's proposal would closely mirror that of a per-beneficiary allotment as long as state Medicaid cost growth exceeds the growth of the per-enrollee cap. ${ }^{13}$ The funding structure we consider is such that in year $t$ with a set of enrollment categories

\footnotetext{
${ }^{13}$ The Medicaid provision in the AHCA is technically a per-enrollee cap on the federal contribution. For a detailed discussion, see Adler, Fiedler, and Gronniger (2017). The number of enrollees in a state, multiplied by the average baseline federal contribution, dictates the maximum amount the federal government will contribute to a state's program. In practice, the AHCA formula would mirror the current matching structure until the cap is reached, whereupon the effective match rate becomes zero. The federal cap is based on current spending, and the federal matching rate is unchanged, implying that incentives for incremental spending per beneficiary would be unchanged by the AHCA until the cap is reached. If per-beneficiary costs grow faster than the cap, the AHCA's incentives are such that states will tend to be willing to spend up to the amount associated with the maximum federal match. States would then face the full cost of incremental spending per beneficiary, but would receive additional funding for covering additional qualifying beneficiaries. As emphasized by Adler, Fiedler, and Gronniger (2017), state cost growth varies nontrivially. States' incentives for incremental spending per beneficiary will thus vary with whether their underlying cost growth exceeds or falls short of the growth of the federal cap.
} 
$C$, state $s$ receives:

$$
\begin{array}{r}
\text { Block Grant }_{s, t}^{P B A}=\sum_{c \in C}\left(\text { Enrollment }_{c, s, t} \times \text { Per-beneficiary spending }_{c, s, \bar{t}} \times \prod_{i=\bar{t}}^{t}\left(1+g_{i}\right)\right) \\
\text { with } C=\{\text { children, adults, disabled, aged, other }\} . \quad(4)
\end{array}
$$

That is, federal funding per category $c \in C$ is the product of enrollment and baseline per-beneficiary spending grown out at rate $g_{i}$. Total federal spending for a state is simply the sum across categories.

\section{Cross-State Distributional Implications of Al- ternative Financing Structures}

In this section we illustrate the implications of status-quo block grants and uniform, need-based grants for baseline distributions of federal dollars across states. We show that the choice of funding structure is highly consequential for cross-state variations in the allocation of federal dollars. Because of its significance to this analysis, we begin by outlining the role of Medicaid expansion under the ACA.

\subsection{Incorporating Medicaid Expansion Under the Affordable Care Act}

When allocating federal funds under any of the financing structures we consider, policymakers must ask how baseline allocations will treat spending associated with Medicaid expansions implemented under the ACA. The ACA made federal funds available to states to finance expansions of Medicaid to cover nearly all individuals

with incomes at or below 138 percent of the poverty line. For this expansion population, the federal government initially covered 100 percent of costs. That match rate 
was scheduled to decline to 90 percent over time. Consequently, the 32 states (counting the District of Columbia) that chose to expand Medicaid (as of January 2017) substantially increased the amount of federal funding they received. In 2015, federal spending through ACA Medicaid expansions reached $\$ 70$ billion, which is roughly 20 percent of total federal Medicaid spending.

Among expansion states, ACA-related federal funding accounts for an average of 19 percent of total Medicaid spending and just under 30 percent of federal spending. These figures vary considerably across states. Figure 1 shows federal ACA expansion funding as a percent of each state's total federal Medicaid funding. In some states, expansion funds make up as much as 40 percent of total federal funding. The treatment of these funds thus has substantive implications for expansion states' budgets and for the redistribution of federal funds under alternative financing structures. On average among these states, expansion funds are equivalent to nearly 9 percent of own-source revenue. The relevance of these funds to state budgets is underscored by the fact that eight expansion states have legislated that the Medicaid expansion be unwound if federal funding falls below a legislatively specified threshold. ${ }^{14}$ In the analysis that follows, we will illustrate key figures with and without the inclusion of ACA-related federal funding.

\subsection{Status-Quo Block Grants}

Under a status-quo block grant, as defined in subsection 2.1, each state receives a block grant equal to its 2015 federal allocation. Grants of this form would involve perfect continuity with the existing federal matching grant structure in the short term. This structure would thus lock in the considerable existing variations in federal

\footnotetext{
${ }^{14}$ The states are Arkansas, Illinois, Indiana, Michigan, Montana, New Hampshire, New Mexico, and Washington. Reports surrounding CBO's score of ACA "repeal-and-replace" legislation in early 2017 suggested that some uncertainty existed regarding the impacts of these provisions. In particular, some expressed doubt about whether states would fully commit to repealing expansion in the event of a reduction in match rates.
} 
allocations to states.

Existing variations are driven by a combination of historical federal match rates and historical state decisions regarding the expansiveness of their Medicaid programs. Relevant margins include states' eligibility rules, the generosity of their benefit packages, and the generosity of their provider payments. Status-quo variations in federal funding per capita, which are presented in figure 2, are substantial. Panel A shows total federal spending inclusive of ACA expansion funds (i.e., the current status quo), while panel B excludes them. In 2015, total federal spending per state resident varied from a low of $\$ 535$ per person in Virginia to more than $\$ 2,700$ in the District of Columbia. Figure 3 illustrates a separate measure of the variation in federal Medicaid spending across states - namely, their federal spending per resident in poverty. Again, we present these data with and without ACA-related federal spending. Inclusive of ACA-related funds, these values range from roughly $\$ 3,700$ in Georgia to more than $\$ 15,000$ in the District of Columbia, Minnesota, and Vermont.

In addition to large absolute differences in funding levels, there are strong geographic variations in federal Medicaid funding. In particular, states on the Pacific Coast and in the Northeast receive relatively large federal allocations per state resident. The opposite is true of states in the Southeast and the Mountain West. This pattern was evident before the ACA but is particularly pronounced with the inclusion of ACA-related funding. This reflects a link between states' pre-ACA Medicaid generosity and their willingness to expand their programs under the ACA.

From the perspective of federal policymaking, it is relevant to consider what forces underlie this variation. Existing variations reflect some combination of differences in underlying need, differences in policy preferences, and differences in the efficiency with which states' programs are run. The relative importance of these factors may be quite relevant for whether existing variations are viewed as a socially desirable allocation or an allocation in need of reform. 


\subsection{Uniform, Need-Based Block Grants}

Under a uniform, need-based block grant, as defined in subsection 2.2, each state receives a grant tied solely to its population and its income per capita relative to national income per capita. Federal allocations would thus be based solely on a metric of need and would cease to be linked to the historical generosity of states' programs. In this section, we illustrate the implications of shifting the 2015 pool of federal funding from status-quo allocations to the allocations implied by the uniform, need-based block grants described by equation (3).

Figure 4 presents the percentage change in federal funding levels under a uniform PCI-based block grant relative to current funding. In panel A we include ACA expansion funds, while in panel B we exclude them. ${ }^{15}$ States in the Southeast and Plains regions tend to see increases in federal funding relative to the status quo. States in the Northeast and on the Pacific Coast tend to lose funding. In general, funding shifts from states with high baseline spending levels toward states with low baseline spending levels. This pattern holds using a variety of metrics for state Medicaid spending needs. Because high-income states tend to have more extensive existing programs (on both a per-resident and per-beneficiary basis), they tend to lose funds under a uniform, need-based allocation. The opposite is true for low-income states.

We illustrate the magnitudes of the funding changes implied by uniform needbased grants in figure 5. We include ACA-related federal spending for this and all subsequent analysis. Panel A shows that funding changes can be quite large. The District of Columbia, for example, would experience a decline of more than 50 percent, while several states would see their federal funding increase by more than 50 percent. Between Texas and New York, which are among the larger gainers and losers, the spread in the relative change amounts to $\$ 1,000$ per capita.

\footnotetext{
${ }^{15}$ Note that the effect of excluding ACA expansion funds is primarily to reduce the overall pool of funding by roughly $\$ 70$ billion.
} 
For perspective, it can be helpful to contrast the magnitudes of these formulas' implications with past analyses from the literature on distributive politics. Berry, Burden, and Howell (2010), for example, estimate that congressional districts represented by a member of the president's political party receive $\$ 40$ per capita more than districts that are not. Levitt and Snyder (1995) analyze spending distributions at the end of an extended period of large Democratic majorities in Congress. Their estimates suggest that decades of control over spending formulas yielded differences that would translate into $\$ 1,000$ current dollars per capita when comparing a district with a Democratic vote share of 25 percent to a district with a Democratic vote share of 75 percent. It is remarkable that this same amount could currently be shifted through straightforward alterations to Medicaid financing formulas.

In panel B of figure 5 we illustrate each state's change in federal funding as a percentage of its total own-source revenue. The magnitudes presented in panel B provide perspective on the gaps state budgets would face due to a shift to the uniform need-based grant structure. Because of their balanced budget requirements, states would need to fill such gaps through a combination of tax increases and spending reductions over short time horizons following federal funding changes.

Because balanced budget requirements bind in the face of deficits, we emphasize the set of states that would experience declines in federal funding. A number of states would experience funding declines that exceed 10 percent of their own-source revenues. In New York, for example, a decline of $\$ 16$ billion is equivalent to 16 percent of own-source revenue. States could make up funding through reductions in spending, though these spending reductions would need to be similarly substantial. The $\$ 16$ billion shortfall in New York, for example, exceeds the entirety of the state's education budget by 30 percent. Elimination of ACA funding through use of a pre-ACA baseline funding level would significantly exacerbate states' shortfalls.

The magnitude of these budgetary shifts makes immediate transitions across fund- 
ing structures disruptive. Funding reforms may thus be likely to incorporate transition periods that allow budgetary adjustments to be smoothed, in particular in states that lose funding. We explore the trade-off between the smoothness of states' transitions and increases in federal spending in section 3.6.

\subsection{Per-Beneficiary Allocations}

Per-beneficiary allocation (PBA) structures give federal legislators an intermediate level of control over the distribution of federal funds. By design, PBA structures deliver greater funds to states with programs that cover relatively large numbers of beneficiaries. The formulas that determine states' allocations per beneficiary, however, remain under federal legislators' discretion.

Legislators have discretion over the extent to which per-beneficiary payments are connected to historical beneficiary costs at the state or national level. The redistribution that would result from allocating spending on the basis of national average spending rather than state-specific spending would be significant, but less dramatic than the redistribution associated with moving from status-quo block grants to uniform, need-based block grants. The desirability of redistributing federal funds depends, once again, on what factors underlie historical variations. As before, the relative roles of underlying need, policy preferences, and efficiency are relevant to whether current allocations are thought to be appropriate or in need of reform.

\subsection{Political Economy of Static Redistribution}

The static distributional implications of Medicaid financing reforms come with political economy considerations. States that gain and lose under alternative systems are not randomly distributed across the political landscape. To better understand the political dynamics underlying this redistribution, we augment panel A of figure 5 with shading that indicates states' outcomes in the 2016 presidential election. In 
the resulting figure 6, Trump states are shaded red, while Clinton states are shaded blue. Divorcing block grants from current Medicaid spending disproportionately benefits Trump states. Notable exceptions include several Republican voting states that have enacted Medicaid expansions under the ACA. These include Alaska, Arkansas, Arizona, Kentucky, and Ohio.

Table 1 summarizes correlations between several state characteristics and the changes in federal funding implied by a shift from the status quo to uniform, needbased grants. More precisely, it presents estimates of equation (5):

$$
\text { Block Grant }_{s}^{U N B}-\text { Block Grant }_{s}^{S Q B}=\beta_{0}+\text { State }_{\text {Traits }} \gamma+\epsilon_{s} .
$$

In the estimates we present, the vector State Traits $_{s}$ includes various combinations of state income per capita, an indicator for implementation of the ACA Medicaid expansion, and Hillary Clinton's vote share in the 2016 presidential election.

Column 1 of table 1 shows that funds would tend to shift from high-income states toward low-income states; an income differential of $\$ 10,000$ per capita predicts a differential funding change of $\$ 320$ per capita. Column 2 shows that funds would tend to shift away from states that expanded their Medicaid programs through the ACA; states that expanded Medicaid would, on average, see their funding decline by nearly $\$ 600$ per capita relative to states that did not expand Medicaid. Column 3 shows that funding would tend to shift away from states that had relatively high Clinton vote shares in the 2016 presidential election; a 10 percentage point higher Clinton vote share predicts a relative funding decline of $\$ 260$ per capita. Together, these three factors predictively explain just under 60 percent of the variation in the differences in states' funding across the regimes under consideration. 


\subsection{Transitioning to a Uniform Allocation System}

The fact that a uniform need-based allocation would significantly redistribute federal funding would make rapid transitions a source of strain on state government budgets. Compliance with balanced budget requirements would require "losing" states to implement large and disruptive spending reductions and/or revenue increases over short time horizons. It is thus useful to consider the design of transition rules.

The design of transition rules involves balancing between competing interests. States with high baseline federal contributions would benefit from slow transitions to alternative regimes. Cushioning these states' losses, however, involves increases in the transition's cost to the federal government. In contrast, rapid transitions will benefit taxpayers in states that stand to gain from shifting to the final allocation. In this section, we analyze the trade-offs associated with transitions of different speeds under an illustrative transition mechanism.

We model a transition rule that allows states to chose between two options - the uniform, need-based block described in section 2.2 or a status-quo block grant. The uniform block is allowed to grow at rate $g_{0}$, so that Block Grant $\operatorname{Grtt}_{s N B}^{U N B}=$ Block Grant $_{s, \bar{t}}^{U N B} \times$ $\left(1+g_{0}\right)^{t-\bar{t}}$, where $\bar{t}$ represents a base year. Similarly, the status-quo block grant is Block Grant ${ }_{s, t}^{S Q B}=$ Block Grant ${ }_{s, \bar{t}}^{S Q B} \times\left(1+g_{1}\right)^{t-\bar{t}}$. We assume $g_{1}<g_{0}$, so that the status-quo allotment grows more slowly than the uniform block grant. Over time, this generates a transition in states' preferences for the uniform grant relative to the status-quo grant. With a transition rule of this form, a state's federal allocation in year $t$ is:

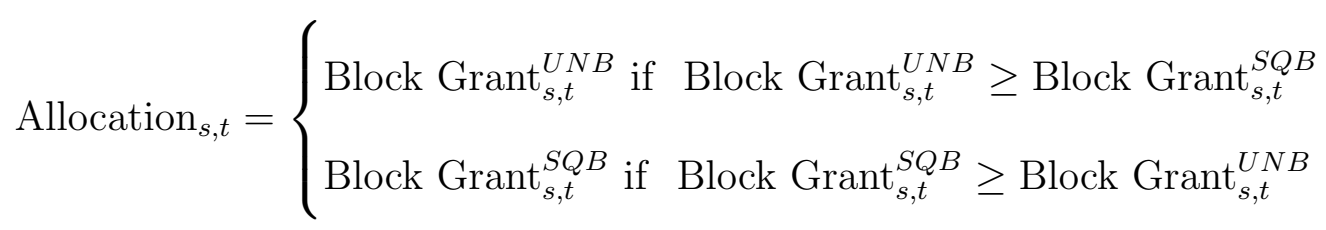

Our simulation uses a base year of 2015 and allows the uniform, need-based block 
to grow at $g_{0}=3.4 \%$ - the Congressional Budget Office's long-run estimate of Medicaid cost growth. We hold $g_{0}$ fixed to focus attention on the implications of alternative specifications of $g_{1}$-the growth rate of the status-quo block grant-for aggregate federal spending.

Figure 7 presents our results. Panel A shows aggregate federal funding under alternative growth rates, while panel B shows the corresponding excess of federal spending relative to an immediate transition, which is revenue neutral by construction. The range of growth rates we consider is motivated by practical considerations of likely transition windows. Twenty-eight states are initially better off under the uniform, need-based allocation and thus chose to transition immediately. By initially holding states harmless, base-year spending is $\$ 55$ billion higher than the current system.

If the status-quo block is held constant in nominal terms (i.e., $g_{1}=0$ ), it will take 16 years before all states choose to switch to the uniform, need-based allocation. Because of its exceptionally high federal funding relative to its per capita income, the District of Columbia would not transition within the 20-year window we consider. Excess federal funding under this design amounts to a substantial $\$ 440$ billion over 20 years, with more than $\$ 350$ billion occurring during the initial 10-year budget window.

Faster transitions require the status-quo block grant to decline in nominal terms (i.e., $\left.g_{1}<0\right)$. While faster transitions reduce the federal government's costs, transition costs remain nontrivial under the growth rates we consider. If $g_{1}=-7 \%$, for example, the transition would take seven years, and federal spending would exceed status quo spending by $\$ 140$ billion over that time period.

Transition costs reflect variations in federal funding under the status quo. That is, high spending states have considerable amounts of "surplus" funding relative to low spending states. Consequently, transition costs can have substantive implications for the federal budget. 


\section{Responsiveness to Business Cycle Fluctuations}

In addition to static distributional effects, alternative funding structures have implications for state governments' exposure to business cycle fluctuations. Standard analyses in the tradition of fiscal federalism highlight the federal government's advantages relative to lower levels of government in the conduct of stabilization policy (Oates, 1972, 1999; Gramlich, 1987). Limitations on states' capacity to engage in countercyclical policy are formalized by their balanced budget requirements, many of which restrict the use of short-term debt to finance general fund expenditures. ${ }^{16}$

To illustrate the implications of block grant design, we simulate the evolution of alternative federal financing structures over the course of the Great Recession. The assumption underlying the exercise is that the actual path of states' Medicaid spending reflected underlying changes in need. This assumption is conservative for our purposes. Spending will tend to rise less than underlying need during a recession because states take actions, like reducing Medicaid's physician payments, to balance their budgets (NASBO, 2011; 2012). Our simulation provides an answer to the following question: Under alternative financing structures, how much would states' own-source contributions have needed to rise to finance the spending that occurred under the existing system?

Our simulation is slightly complicated by the American Reinvestment and Recovery Act (ARRA). The ARRA increased federal Medicaid funding from 2009 to 2011 through increases in the applicable Medicaid match rates. Our simulation of the existing system nets ARRA spending out of the federal government's contributions.

\footnotetext{
${ }^{16}$ For a recent discussion, see Bagley (2017). Research on the implications of states' balanced budget requirements for their responsiveness to short-run shocks includes Poterba (1994); Clemens and Miran (2012); and Clemens (2013). Additional research on the relevance of fiscal institutions for state budgeting practices includes Bohn and Inman (1996); Levinson (1998); Hou and Smith (2006, 2010); Smith and Hou (2013); Poterba (1995); and Costello, Petacchi, and Weber (2012). Zhao (2014) highlights that the need for fiscal adjustment in response to shocks is driven in part by the fact that states save too little in their rainy day funds to smooth their expenditures during downturns.
} 
We do this so that the baseline describes how the current system would operate in the absence of ad hoc interventions by Congress. We net out spending through the ARRA by assuming that each state would have paid the same fraction of its program's costs from 2009 to 2011 as they paid prior to 2009 (about 40 percent, on average). ${ }^{17}$

\subsection{Acyclical Block Grants}

We first consider the acyclical block grant allocations described by equation (1). For this section's purposes, the key feature of these grants is that they make no adjustments for fluctuations in economic conditions. For our analysis of the Great Recession, we set the base year to $\bar{t}=2006$. We consider growth rates equal to the consumer price index for all urban consumers (CPI-U) and the consumer price index for medical care services (CPI-M).

Figure 8 presents the resulting paths of federal and state funding. Actual federal and state spending are indicated by solid lines. Federal and state funding under the acyclical block are shown as dashed lines. State funding is defined as the amount of spending required by states to achieve realized total Medicaid spending, given the changes to federal funding.

Acyclical block grants can lead federal funding to rise much less than matching grants during economic downturns. While this qualitative result is unsurprising, the magnitudes are informative. If federal funding had grown with the rate of overall inflation (CPI-U), acyclical block grants would have risen by $\$ 22$ billion, from $\$ 178$ billion to $\$ 200$ billion from 2006 to 2011 . Under the matching grant structure, nonARRA federal spending grew by a more substantial $\$ 63$ billion. The rise in federal funding through acyclical block grants would thus have fallen roughly $\$ 41$ billion short of the rise under the current system. If federal funding had grown instead with medical inflation (CPI-M), the relative shortfall in 2011 would have been $\$ 29$ billion.

\footnotetext{
${ }^{17}$ Our estimate of ARRA Medicaid spending - \$102 billion - is nearly identical to figures from the Kaiser Family Foundation: https://kaiserfamilyfoundation.files.wordpress.com/2013/01/8252.pdf
} 
It is again useful to express variations in federal funding as a share of states' ownsource revenues. Figure 9 illustrates the relative shortfalls that would have occurred in 2011 under a nonresponsive block grant that grew at the rate of medical inflation from 2006 through 2011. To maintain the spending that occurred under the existing system, 44 states would have needed to increase their contributions. Looking across all states, the shortfall averages just over 2 percent of own-source revenues. Under a nonresponsive block grant that increases at $\mathrm{CPI}-\mathrm{U}$, this increases to nearly 3.5 percent.

\subsection{Countercyclical Block Grants}

We now illustrate the potential for block grants to incorporate short-term adjustments for business cycle fluctuations. Specifically, equation (6) describes a block grant that increases with inflation and adjusts with the national unemployment rate. We call such grants countercyclical block grants (CCB). For a state $s$ in year $t$, the block grant is equal to:

$$
\text { Block Grant }{ }_{s, t}^{C C B}=\text { Fed Funding }{ }_{s, \bar{t}} \times \prod_{i=\bar{t}}^{t}\left(1+g_{i}\right)\left(1+\left(U_{t}-\bar{U}\right) \times \text { Cyclical Factor }\right) .
$$

We again base initial federal allocations on their levels from 2006. Equation (6) augments equation (1) with an adjustment (Cyclical Factor) driven by the difference between the national unemployment rate, $U_{t}$, and an estimate of its long-run natural rate, $\bar{U}$. Our simulation sets the natural rate to $\bar{U}=5 \%$. The choice of Cyclical Factor dictates the extent to which the block grant adjusts in response to changes in the unemployment rate. In our example, we construct a block grant that is roughly as generous over this time period as was the existing matching grant structure. We scale such that, with the growth factor $g_{t}$ set to the rate of CPI-M, the federal government spends approximately the same amount in total from 2006 to 2012 as under the 
current system. The Cyclical Factor that achieves this outcome is 0.03. That is, aggregate federal spending increases 3 percent for every percentage point increase in the national unemployment rate.

Figure 10 illustrates aggregate state and federal spending under the current system and both the acyclical and countercyclical block grants. The evolution of federal funding is markedly different across regimes. In comparison to the current system, federal spending under the countercyclical block grant responds relatively rapidly to the economic downturn beginning in 2008. As the recession fades, the growth of the countercyclical grant declines.

\subsection{Per-Beneficiary Allocations}

Per-beneficiary allocations respond automatically to economic downturns because federal funding expands with Medicaid enrollment. Growth in the number of enrollees is the primary driver of short-run Medicaid expenditures. Consequently, the dynamics of per-beneficiary grants would differ relatively little from the dynamics of the current system. Nonetheless, there are subtle design issues worth considering. In particular, the characteristics of marginal enrollees matter. If, for example, the typical individual made eligible by a recession is healthier than the average Medicaid beneficiary, the per-beneficiary allocation would be "too generous." That is, the per-beneficiary allocation could exceed the cost of the marginal enrollee. The direction and magnitude of selection along these lines has straightforward implications for the relationship between increases in federal funds relative to funding needs.

\subsection{Additional Cyclicality in State Government Finances}

The strains state governments face during downturns extend beyond those associated with their Medicaid programs. Most notably, states' tax bases contract at the same time their Medicaid enrollments rise. We conclude this section by observing that the 
Cyclical Factor in a countercyclical block grant design can be used to stabilize state budgets beyond their Medicaid spending needs.

The contraction of revenue bases during recessions places significant strain on state budgets. Estimates of the short-run elasticity of personal income and sales tax revenue with respect to aggregate state income typically exceed one (e.g., Dye 2004; Bruce, Fox, and Tuttle 2006). Relative to 2007 (the nearest full year preceding the recession), per capita personal incomes had fallen by 4.5 percent as of 2009. State tax revenues would thus have likely fallen by 5 percent or more in the absence of rate increases. A 5 percent decline on aggregate 2007 state income and sales tax revenue of $\$ 730$ billion translates into a $\$ 35$ billion decline in revenue. With decreasing tax revenues, rising Medicaid costs, and balanced budget requirements, business cycle fluctuations can exert substantial pressure on state finances.

Countercyclical block grants provide a straightforward means for easing the adjustments required to stabilize state government budgets during economic downturns. If revenue declines are of a magnitude similar to increases in Medicaid program needs, for example, state budgets could be stabilized by simply doubling the Cyclical Factor in the countercyclical block grant formula. An important feature of this approach to budget stabilization is that it would be embedded in the block grant structure as an automatic stabilizer. That is, it could be designed and implemented in advance rather than legislated on an ad hoc basis as an economic downturn unfolds.

\section{Long-Run Growth Rates and State Incentives for Generous Coverage}

Thus far we have focused on the cyclical and cross-sectional implications of Medicaid financing reforms. We now turn to the long run. Over the long run, the evolution of federal Medicaid financing depends largely on the rates at which federal allocations 
are legislated to grow. We emphasize two points. First, growth rates can play an important role in shaping states' incentives for expanding coverage. Second, the growth of federal financing has substantial implications for the long-run division of financing between the state and federal governments. This can be viewed in part as a determinant of the long-run floor on the size of states' Medicaid programs.

The financing arrangements we analyze differ significantly in their implications for the rates at which the federal government subsidizes both the intensive and extensive margins of Medicaid program generosity. Among the financing arrangements we consider, only the current matching structure subsidizes the generosity of states' programs along intensive margins. Neither traditional block grants nor per-beneficiary block grants provide incremental subsidy for states that expand the sets of services they cover or increase the generosity of their payments to health care providers.

While per-beneficiary federal allocations do not subsidize the intensive margin of coverage generosity, they do subsidize the extensive margin. On the extensive margin, per-beneficiary allocations thus perform like matching grants; when a state covers an additional beneficiary, it receives an additional per-beneficiary payment. Matching grants similarly subsidize coverage expansions, as each dollar a state spends generates an increase in federal funds. Traditional block grants, by contrast, provide no subsidy for coverage on the extensive margin.

The per-beneficiary allocation structure has additional implications for states' incentives to enroll relatively high-cost individuals. While a per-beneficiary allotment maintains an extensive margin subsidy, that subsidy is constant across individuals within an enrollment category. The risk of spending in excess of the average is thus borne entirely by the state, much as with the risks faced by health maintenance organizations. As emphasized by Layton, Montz, and McGuire (2017), this incentivizes states to enroll relatively low-cost individuals within each category across which fed- 
eral allocations are differentiated. ${ }^{18}$

With these issues in mind, we consider the implications of the long-run growth rate of federal funding. The key point is that growth rates drive the long-run evolution of the extensive margin subsidy under the per-beneficiary allocation structure. We illustrate this with reference to the recent AHCA proposal. As proposed in the AHCA, states' initial per-beneficiary allocations would cover roughly 60 percent of the cost of covering new beneficiaries. The proposal allows these allocations to grow at a rate equal to the consumer price index for medical care (CPI-M). This growth rate is slower than projected growth in health expenditures per capita. Consequently, the generosity of the AHCA's subsidy for coverage expansions would decline over time.

CBO projects that spending on Medicaid beneficiaries will grow at a rate equal to GDP growth plus 1 percentage point from 2028 to $2047 .{ }^{19}$ Per-beneficiary spending growth is projected to outpace the AHCA's allocations by the rate of real GDP growth. ${ }^{20}$ From 2018 to 2047, CBO projects that real GDP will grow at a rate of 1.9 percent per year.

Figure 11 presents simulations of the evolution of the fraction of new beneficiaries' costs that would be covered by per-beneficiary allocations that grow at alternative rates. The rates we consider include CPI-M, CPI-U, and the growth rate of per capita medical expenditures. From 2018 to 2047, we project that the extensive margin subsidy rate would decline from 60 percent to 35 percent with a growth rate of CPI-M. Over this same time period, the subsidy rate associated with allocations that grow at a rate of CPI-U would decline by more than half. Allocations that grow with health care costs would, by design, result in a constant subsidy rate. As emphasized by

\footnotetext{
${ }^{18}$ For evidence on the effects of selection incentives in the Medicaid managed care setting, see Kuziemko, Meckel, and Rossin-Slater (2013).

${ }^{19} \mathrm{CBO}$ projects that Medicaid spending growth in earlier years will be affected by coverage changes embedded in current law, from which we wish to abstract.

${ }^{20} \mathrm{CBO}$ 's projection of per-beneficiary cost growth is real GDP growth $+\mathrm{CPI}-\mathrm{U}+1$ percentage point, while the AHCA's allotments grow at a rate of CPI-M. Because CPI-M is projected to grow at a rate of CPI-U +1 percentage point, per-beneficiary cost growth is projected to exceed the growth of the AHCA's allotments by the rate of real GDP growth.
} 
Adler, Fiedler, and Gronniger (2017), Medicaid cost growth has varied substantially across states in recent years. It is thus worth noting that even with a growth rate equal to average health care cost growth, the effective subsidy may vary across states over time.

The evolution of extensive margin subsidies has direct bearing on the responsiveness of federal funding to business cycle fluctuations. As discussed in section 4, the current funding structure automatically responds to economic downturns as higher enrollment drives spending increases. Federal funding under a per-beneficiary allotment retains some of this feature by rising in tandem with enrollment increases. It is thus relevant that the extent to which federal funding increases during economic downturns mechanically decreases as the extensive margin subsidy is reduced. If the extensive margin subsidy declines, the responsiveness of federal Medicaid dollars to business cycle fluctuations will erode.

What role does the growth of federal funding play under a traditional block grant structure? Under traditional block grants, federal financing subsidizes states' decisions on neither the intensive nor the extensive margin of coverage generosity. The marginal subsidy rate is thus zero both at present and in the future regardless of the growth rate. With traditional block grants, federal funding becomes a form of foundation aid (Hoxby, 2001). So long as this funding remains contingent on its use in the provision of health insurance, federal funding effectively imposes a floor on a state's overall Medicaid funding. If it is not made contingent, it may in practice become a form of general fund support. Under block grant structures, rules establishing the population groups and sets of health care services that states must cover are the primary lever through which the federal government influences the generosity of states' programs. Examples of such rules in other contexts include the "Maintenance of Effort" requirements associated with federal education funds and the 1996 federal welfare reform. 


\section{Potential State Responses to Declines in Federal Funding}

Our analysis has explored how alternative financing arrangements affect the overall magnitude and distribution of federal contributions to states' Medicaid programs. We find that alternative structures can have significant implications for the federal government's contributions over the very short run, over the course of the business cycle, and over the long run. We conclude by considering the channels along which states might respond to such shifts, and in particular to declines in federal support. That is, we discuss who is likely to bear the incidence of federal funding declines and how that incidence may vary with institutional features of alternative Medicaid financing reforms.

The incidence of declines in federal funding depends crucially on the channels through which states elect to restore balance to their budgets. Options include maintaining expenditure levels by replacing lost federal funds with own-source revenues, reducing Medicaid expenditures, and reducing expenditures elsewhere in the budget. Incidence may thus be born by a combination of those who pay state taxes and fees, Medicaid beneficiaries, health care providers, and the beneficiaries of other programs whose budgets are affected.

Historical experience suggests that a mix of these groups has borne the incidence of adjustments to states' budgetary shortfalls over the business cycle. Surveys from the National Association of State Budget Officers (NASBO), for example, suggest that recessions lead states to enact an eclectic mix of increases in tax rates, increases in fees, reductions in spending outside of their Medicaid programs, and reductions in spending inside their Medicaid programs. Reported Medicaid program changes include reductions in provider payment rates, reductions in optional benefit packages such as dental care, and expansions in the prevalence of managed care models. 
States' decisions regarding the channels through which they adjust may be shaped by a combination of political, institutional, and economic forces. In the discussion that follows, we highlight the range of considerations that may be relevant for states' responses to the funding arrangement envisioned by the AHCA proposal. We begin by discussing the implications of the proposal's purely economic incentives, then we consider the potential relevance of political and institutional factors.

The AHCA proposal would convert federal funding into a per-beneficiary allotment that grows less quickly than projected health expenditures. As discussed above, the proposal eliminates federal subsidy for "intensive" margins of coverage generosity. States may respond to the elimination of this subsidy by reducing the generosity of both their benefit packages and their provider payments. As per-beneficiary allotments decline in relation to expected cost, the proposal would similarly reduce the federal subsidy of coverage on the extensive margin. States may thus respond to this aspect of the proposal by reducing the generosity of their eligibility rules. The incidence of these changes in the incentives associated with federal funding formulas would fall on a combination of health care providers, ongoing beneficiaries whose benefits become less generous, and potential beneficiaries whose eligibility fails to materialize. The beneficiaries of reduced spending would, in general, consist of taxpayers.

Political and institutional factors may have high relevance for states' responses to alternative financing arrangements. Politically, it may matter whether voters view existing benefit arrangements as being excessive, insufficient, or roughly in line with their preferences. Criticisms of proposals that reduce long-run funding growth often articulate the view that the incidence of federal spending declines will be borne by the Medicaid program's current and intended beneficiaries. This will tend to be true if voters perceive that their programs' costs exceed their benefits, such that they would direct funds to alternative uses if federal subsidy rates decline.

Institutionally, it is important to bear in mind that subsidies are not the only lever 
through which federal policy shapes states' Medicaid programs. Additional levers include "Maintenance of Effort" (MOE) requirements and, more generally, federal rules that dictate what constitutes a Medicaid program that is "compliant" for receipt of the block grant. The structure of block grants administered through the Temporary Assistance for Needy Families (TANF) program provide a useful illustration. ${ }^{21}$ Under TANF's funding design, the size of each state's block grant is contingent on whether its spending satisfies its MOE requirement. In principle, states were required to spend roughly as much as they did on welfare before the introduction of TANF. When a state falls short of its MOE requirement, the federal government's contribution declines dollar-for-dollar. In this way, the MOE requirement makes it costly for states to reduce their spending on the program. Through levers of this form, the federal government can exercise substantial influence over the design of states' Medicaid programs whether it maintains a matching grant structure or transitions to either a block grant or a per-beneficiary allocation structure.

\section{Conclusion}

We have assessed the implications of alternative Medicaid financing structures along three dimensions. First, alternative financing mechanisms can significantly alter the distribution of federal dollars across states. A uniform, need-based block grant, for example, would reduce federal funds by the equivalent of 10 percent of several "losing" states' own-source revenues. Second, financing mechanisms differ in the extent to which they shield state government finances from the business cycle. During the Great Recession, we show that an acyclical block grant would have reduced federal spending by an average of 2 to 3.5 percent of states' own source revenues, relative to the current matching structure. Third, alternative financing mechanisms have quite

\footnotetext{
${ }^{21}$ For a thorough discussion of the TANF program, including its funding structure, see Ziliak (2015).
} 
different implications for the incentives states face when deciding how generous to make their programs. We show that the growth rates specified for per-beneficiary allotments like those envisioned by the American Health Care Act (AHCA) have significant implications for states' incentives to cover new beneficiaries over the long run. The growth rate stipulated by the AHCA, for example, would reduce the rate at which the federal government subsidizes coverage of new beneficiaries by nearly half within 30 years.

We conclude by connecting these issues to classic themes from the literature on fiscal federalism (Oates, 1972, 1999). Oates (1999) observes that "At the most general level, this theory contends that the central government should have the basic responsibility for the macroeconomic stabilization function and for income redistribution in the form of assistance to the poor." ${ }^{22}$ Considerations connected to fiscal federalism thus argue for a substantial federal role in the financing and management of Medicaid. Fiscal federalism envisions a prominent federal role in financing expenditures that are redistributive and evolve countercyclically. The Medicaid program quite clearly fits both of these criteria. At the same time, state-level program management facilitates the use of local information in designing benefits that most effectively meet beneficiaries' needs.

Our analysis illustrates how the design of federal transfers shapes states' incentives and is thus an important determinant of the generosity of the redistribution that occurs through states' Medicaid programs. Society's commitment to financing this redistribution is an issue that must be settled through the political process. We thus conclude by observing that fiscal federalism's prescriptive content can only take our analysis so far.

\footnotetext{
${ }^{22}$ Limitations on states' stabilization efforts stem from both their balanced budget requirements and the policy instruments at their disposal. Limitations on states' redistributive efforts relate to migration; individuals can move to and from localities based on the structure or generosity of social programs.
} 


\section{References}

Adler, L., M. Fiedler, and T. Gronniger (2017): "Effects of the Medicaid PerCapita Cap Included in the House-Passed American Health Act," White paper, The Brookings Institution.

BAGLEy, N. (2017): "Federalism and the End of Obamacare," Yale Law Journal (April 24), http://www.yalelawjournal.com/forum/federalism-and-the-end-ofobamacare.

Baicker, K., J. Clemens, and M. Singhal (2012): "The Rise of the States: US fiscal Decentralization in the Postwar Period," Journal of Public Economics, 96(11), 1079-1091.

Bernd-Spahn, P. (2007): "Equity and Efficiency Aspects of Interagency Transfers in a Multigovernment Framework," Intergovernmental Transfers, Principles and Practice, pp. 75-106.

Berry, C. R., B. C. Burden, and W. G. Howell (2010): "The President and the Distribution of Federal Spending," American Political Science Review, 104(04), 783-799.

Boadway, R. W., And A. Shah (2007): Intergovernmental Fiscal Transfers: Principles and Practices. World Bank Publications.

Bohn, H., and R. P. Inman (1996): "Balanced-Budget Rules and Public Deficits: Evidence from the US States," in Carnegie-Rochester conference series on public policy, vol. 45, pp. 13-76.

Bruce, D., W. F. Fox, and M. H. Tuttle (2006): "Tax Base Elasticities: A Multi-State Analysis of Long-Run and Short-Run Synamics," Southern Economic Journal, pp. 315-341.

Card, D., And A. A. Payne (2002): "School Finance Reform, the Distribution of School Spending, and the Distribution of Student Test Scores," Journal of Public Economics, 83(1), 49-82.

Clemens, J. (2013): "State Fiscal Adjustment During Times of Stress: Possible Causes of the Severity and Composition of Budget Cuts," Discussion paper, University Library of Munich, Germany.

Clemens, J., And S. Miran (2012): "Fiscal Policy Multipliers on Subnational Government Spending," American Economic Journal: Economic Policy, 4(2), 4668 .

Costello, A. M., R. Petacchi, and J. Weber (2012): "The Hidden Consequences of Balanced Budget Requirements," MIT Sloan School of Management Working Paper. 
Dye, R. F. (2004): “State Revenue Cyclicality," National Tax Journal, pp. 133-145.

Gramlich, E. M. (1987): "Subnational Fiscal Policy," Perspectives on Local Public Finance and Public Policy, 3(3-27).

Helms, R. (2007): The Medicaid Commission Report: A Dissent. American Enterprise Institute for Public Policy Research.

Hou, Y., And D. L. Smith (2006): “A Framework for Understanding State Balanced Budget Requirement Systems: Reexamining Distinctive Features and an Operational Definition," Public Budgeting \& Finance, 26(3), 22-45.

(2010): "Do State Balanced Budget Requirements Matter? Testing Two Explanatory Frameworks," Public Choice, 145(1-2), 57-79.

Hoxby, C. M. (2001): "All School Finance Equalizations are Not Created Equal," The Quarterly Journal of Economics, 116(4), 1189-1231.

Jackson, C. K., R. C. Johnson, and C. Persico (2016): "The Effects of School Spending on Educational and Economic Outcomes: Evidence from School Finance Reforms," The Quarterly Journal of Economics, 131(1), 157-218.

Kuziemko, I., K. Meckel, and M. Rossin-Slater (2013): "Do Insurers RiskSelect Against Each Other? Evidence from Medicaid and Implications for Health Reform," NBER Working Paper 19198.

Lambrew, J. M. (2005): "Making Medicaid a Block Grant Program: An Analysis of the Implications of Past Proposals," Milbank Quarterly, 83(1), 41-63.

Layton, T., E. Montz, And T. McGuire (2017): "The Downstream Consequences of Per Capita Spending Caps in Medicaid," http://healthaffairs.org/blog/2017/06/26/the-downstream-consequences-ofper-capita-spending-caps-in-medicaid/.

Levinson, A. (1998): "Balanced Budgets and Business Cycles: Evidence from the States," National Tax Journal, pp. 715-732.

Levitt, S. D., And J. M. SNyder (1995): "Political Parties and the Distribution of Federal Outlays," American Journal of Political Science, pp. 958-980.

Oates, W. E. (1972): Fiscal Federalism. Edward Elgar Publishing. (1999): "An Essay on Fiscal Federalism," Journal of Economic Literature, $37(3), 1120-1149$.

PARK, E., And M. Broaddus (2011): "Medicaid Block Grant Would Shift Financial Risks and Costs to States," Center on Budget and Policy Priorities.

Poterba, J. M. (1994): "State Responses to Fiscal Crises: The Effects of Budgetary Institutions and Politics," Journal of Political Economy, 102(4), 799-821. 
(1995): "Balanced Budget Rules and Fiscal Policy: Evidence from the States," National Tax Journal, 48(3), 329-336.

SAto, M. (2007): "The Political Economy of Interregional Grants," Public Sector Governance and Accountability Series-Intergovernmental Fiscal Transfers: Principles and Practices, pp. 173-197.

Smart, M. (2007): "The Incentive Effects of Grants," Intergovernmental Fiscal Transfers, Washington: Banco Mundial, pp. 203-223.

Smith, D. L., And Y. Hou (2013): "Balanced Budget Requirements and State Spending: A Long-Panel Study," Public Budgeting 6 Finance, 33(2), 1-18.

Von Hagen, J. (2007): "Achieving Economic Stabilization by Sharing Risk Within Countries," Intergovernmental Fiscal Transfers: Principles and Practice. Washington, DC: World Bank, pp. 107-29.

Zhao, B. (2014): "Saving for a Rainy Day: Estimating the Appropriate Size of US State Budget Stabilization Funds," Discussion paper, Federal Reserve Bank of Boston.

Ziliak, J. P. (2015): "Temporary Assistance for Needy Families," in Economics of Means-Tested Transfer Programs in the United States, volume 1, ed. by R. A. Moffitt, pp. 303-393. University of Chicago Press. 


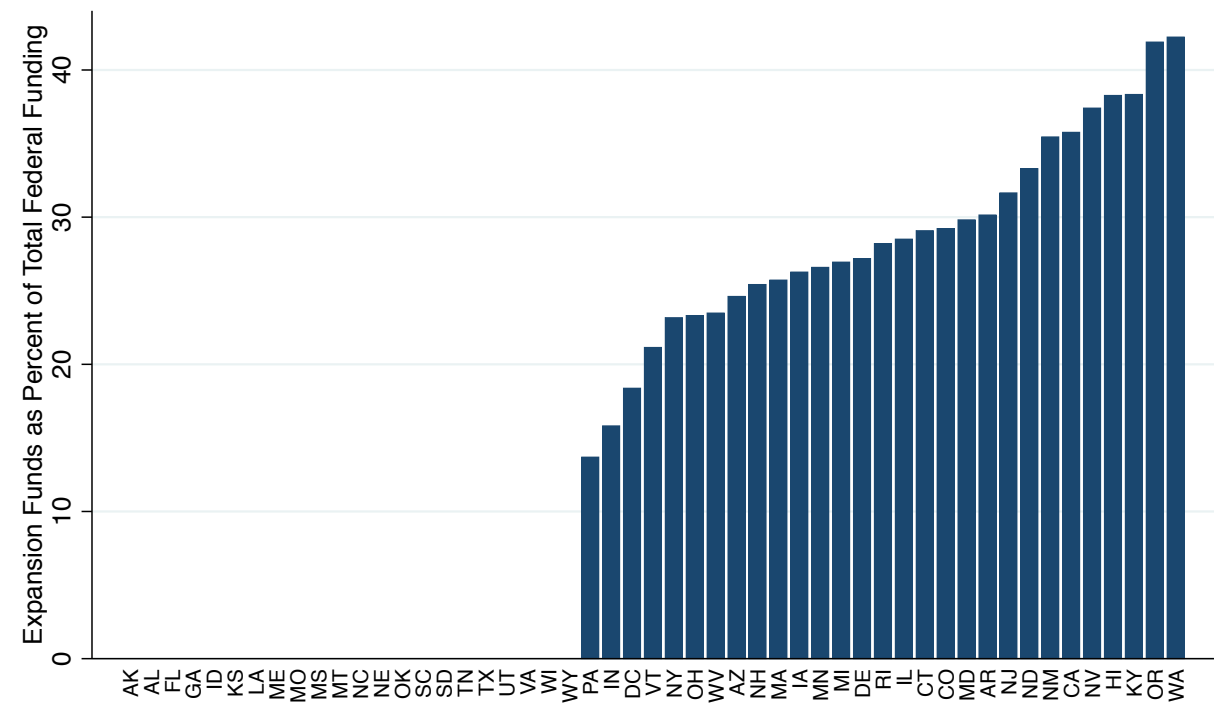

\section{Panel B: Federal Expansion Funds as a Percentage of Own-Source Revenue}

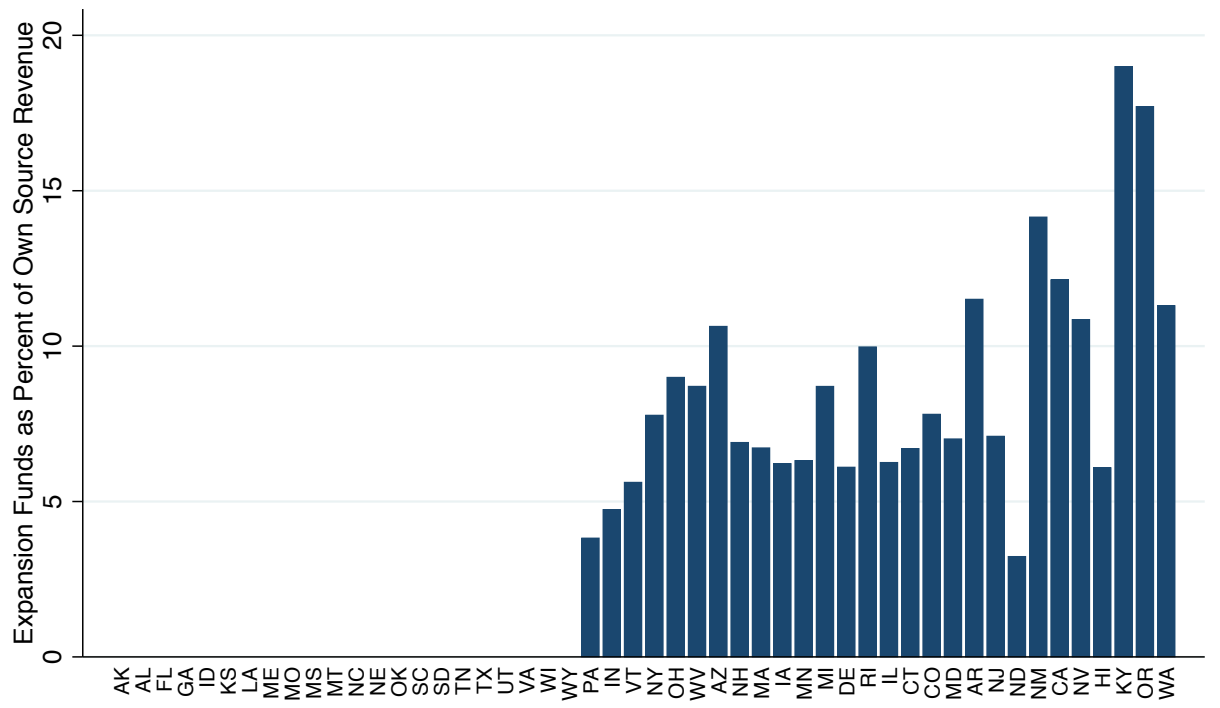

Figure 1: Federal Expansion Funding Across States: This figure illustrates federal funding for Medicaid recipients in the ACA expansion group (group VIII enrollees) across states. Panels A and B show federal funding for the newly eligible as a percentage of each state's total federal funding and own-source revenue, respectively. Data on spending are taken from Form CMS-64 for fiscal year 2015. Total federal spending is the sum of the federal share of total computable net expenditures for the medical assistance program and the federal share of total computable net expenditures for administration. Group VIII spending includes spending on all recipients within this enrollment category, including those that are newly and not newly eligible. Note that states which expanded in September of 2015 or later-Alaska, Louisiana, and Montana-have zero spending in our data for fiscal year 2015. Data on states' own-source revenues are taken from the 2014 Annual Survey of State and Local Government Finances, which was the latest survey available at the time we conducted our analysis. 
Federal Medicaid Spending per State Resident in 2015

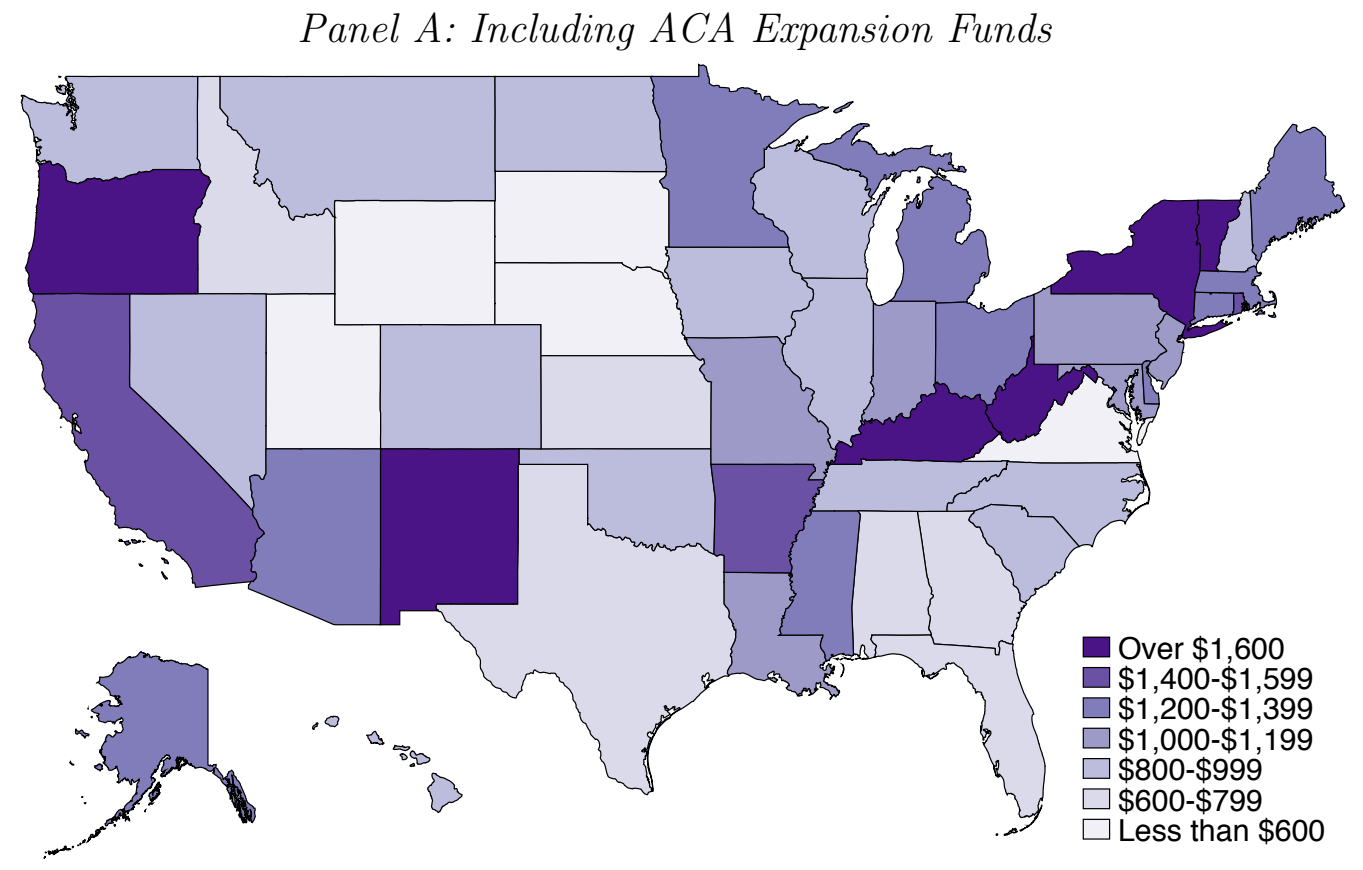

Panel B: Excluding ACA Expansion Funds

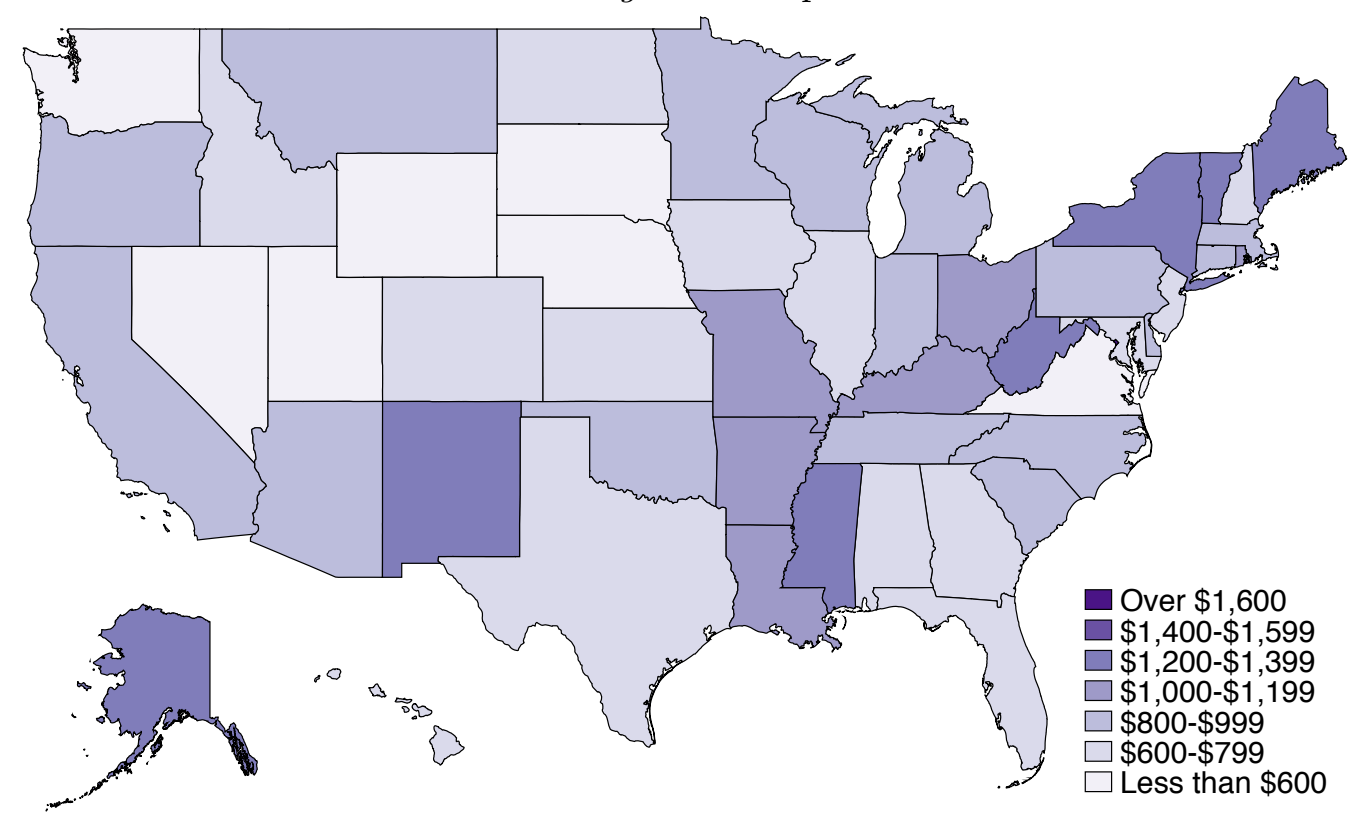

Figure 2: Federal Medicaid Spending per State Resident in 2015: This figure presents federal Medicaid spending per state resident. Panel A includes federal funding associated with the ACA Medicaid expansion population, while panel B excludes these funds. Spending data are from Medicaid financial management reports submitted by states on Form CMS-64. Total federal spending is the sum of the federal share of total computable net expenditures for the medical assistance program and the federal share of total computable net expenditures for administration. Group VIII spending includes spending on all recipients within this enrollment category, including those that are newly and not newly eligible. State populations are estimated using data from the Census Bureau's March 2016 Current Population Survey, as processed by the Kaiser Family Foundation. 
Federal Medicaid Spending per Person in Poverty in 2015

Panel A: Including ACA Expansion Funds

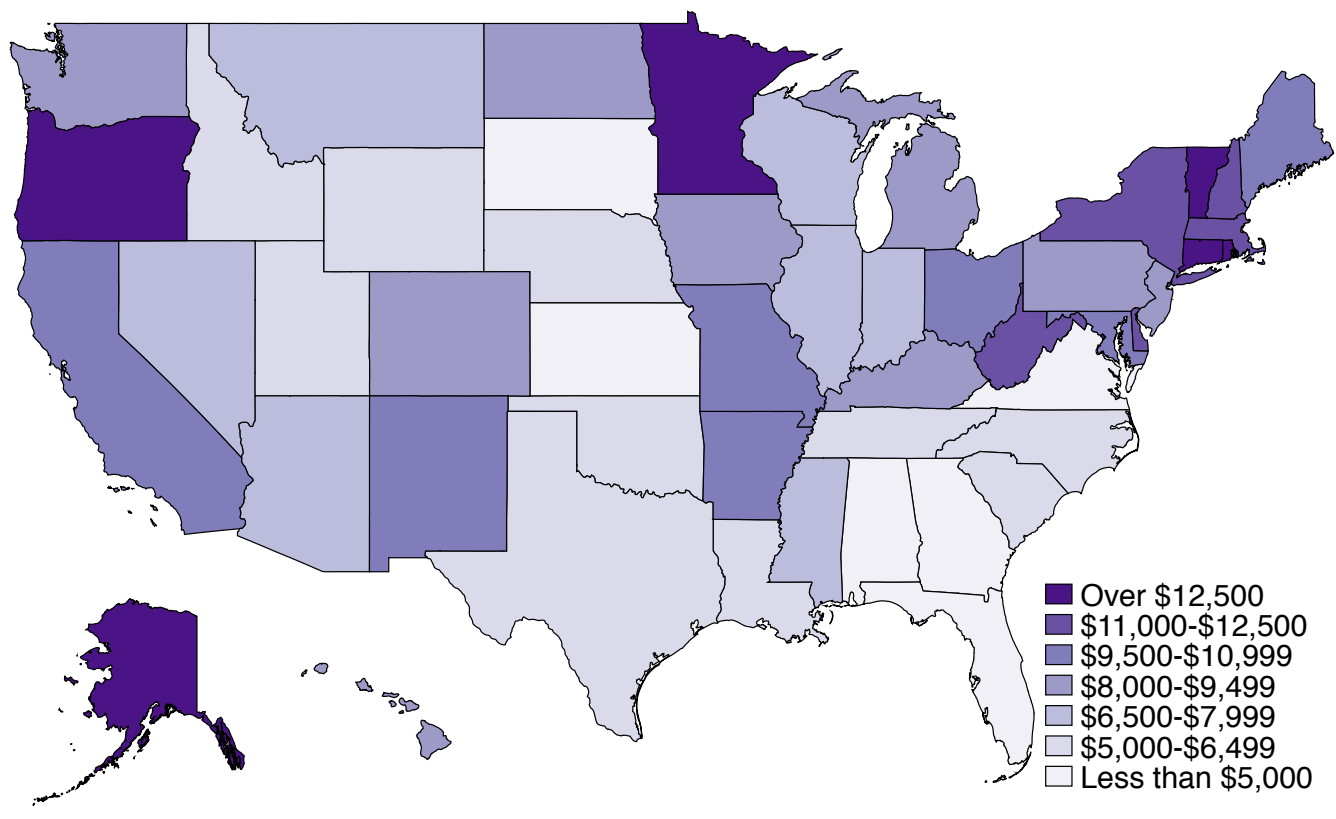

Panel B: Excluding ACA Expansion Funds

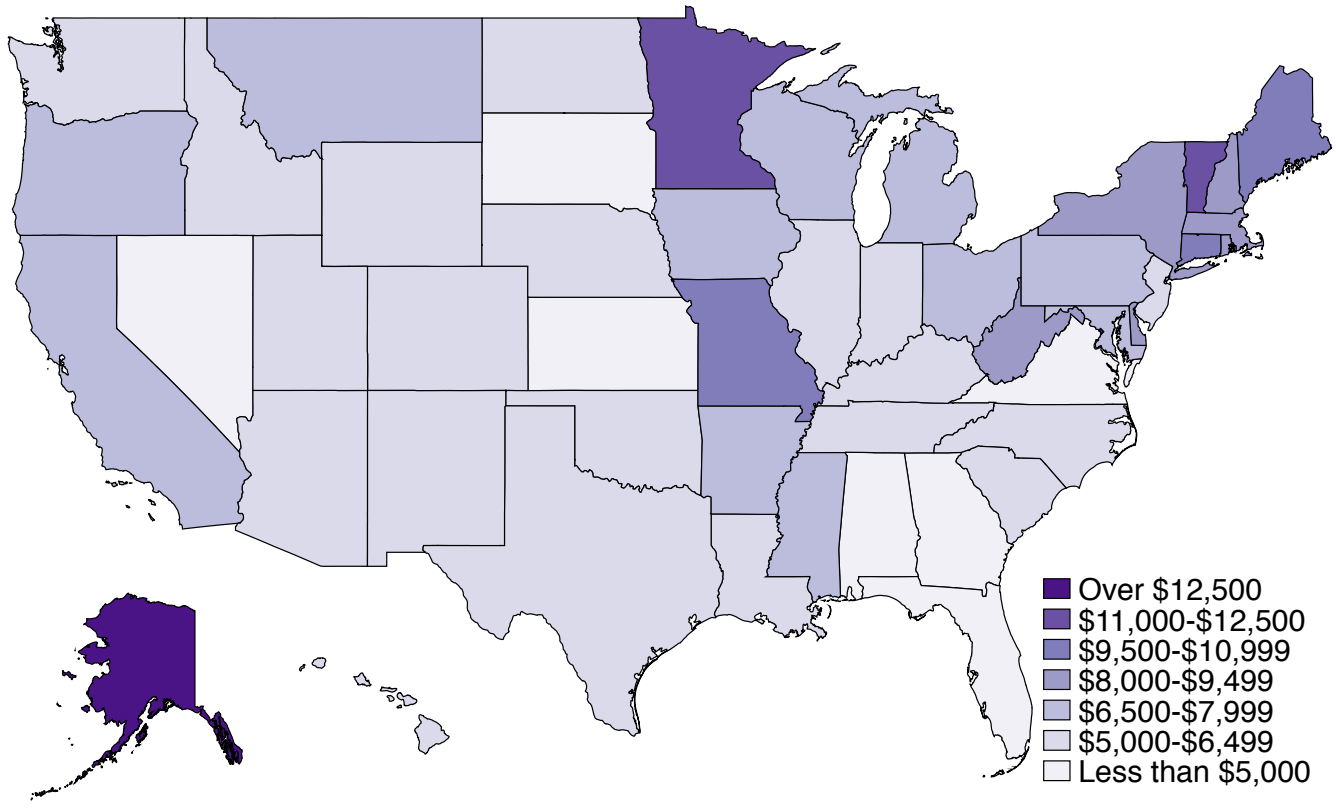

Figure 3: Federal Medicaid Spending per Person in Poverty in 2015: This figure presents federal Medicaid spending per person in poverty, by state. Panel A includes federal funding associated with the ACA Medicaid expansion population, while panel B excludes these funds. Spending data are from Medicaid financial management reports submitted by states on Form CMS-64. Total federal spending is the sum of the federal share of total computable net expenditures for the medical assistance program and the federal share of total computable net expenditures for administration. Group VIII spending includes spending on all recipients within this enrollment category, including those that are newly and not newly eligible. Estimates of states' populations in poverty are constructed using the Census Bureau's March 2016 Current Population Survey, as processed by the Kaiser Family Foundation. 
Percentage Change in Federal Medicaid Funding under a Uniform, Need-Based Block Grant

\section{Panel A: Including ACA Expansion Funds}
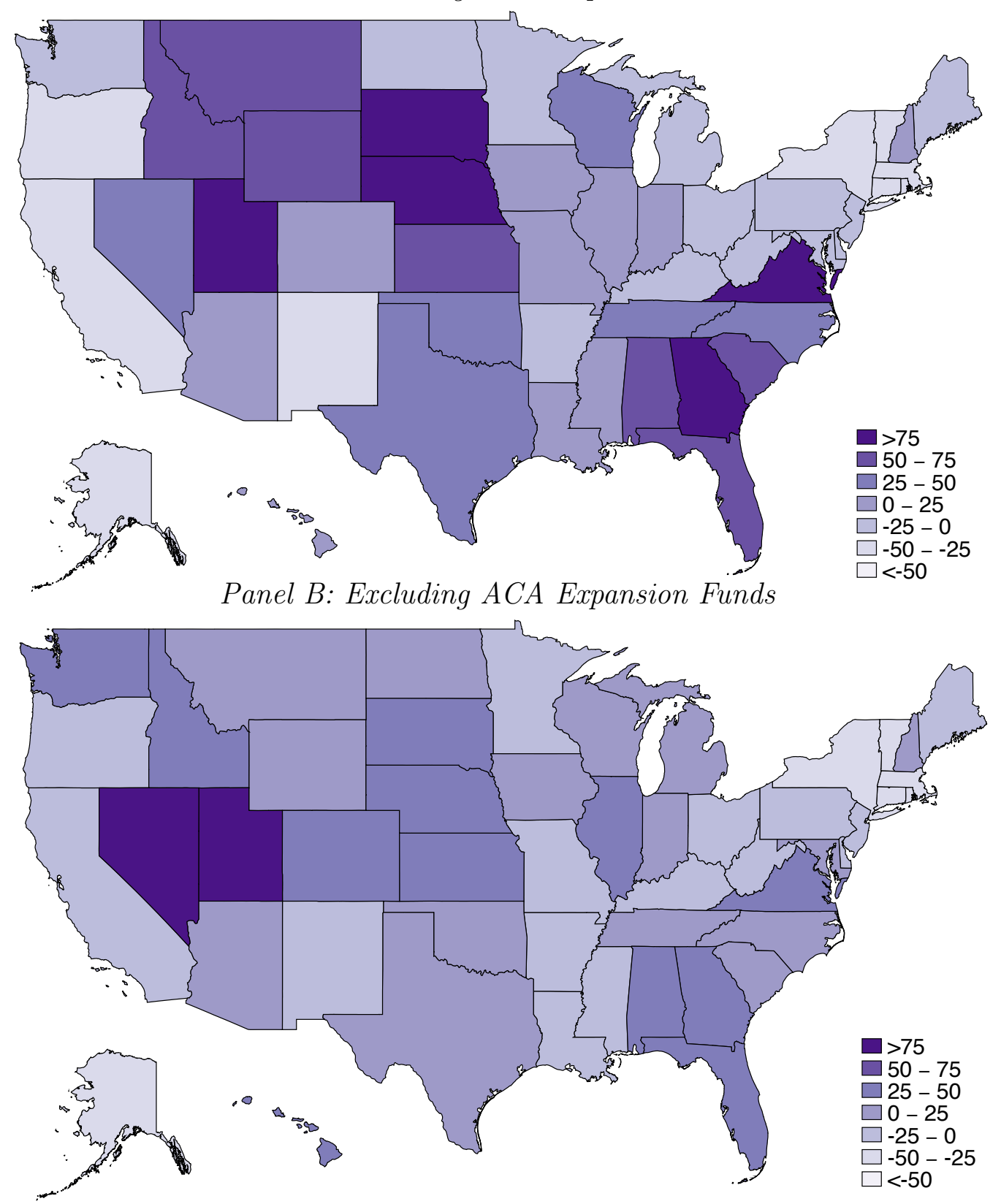

Figure 4: Percentage Change in Federal Medicaid Funding under a Uniform, NeedBased Block Grant: This figure presents the percentage change in federal Medicaid funding by state under a uniform, need-based block grant relative to the current system. Each state's needbased block is determined by equation (3). Panel A includes federal funding associated with the ACA Medicaid expansion population, while panel B excludes these funds. Total federal spending is calculated from Medicaid financial management reports submitted by states on Form CMS-64. Total federal spending is the sum of the federal share of total computable net expenditures for the medical assistance program and the federal share of total computable net expenditures for administration. Group VIII spending includes spending on all recipients within this enrollment category, including those that are newly and not newly eligible. Data on states' personal income per capita are taken from the Bureau of Economic Analysis. 
Changes in Federal and State Medicaid Funding under a Uniform, Need-Based Block Grant

Panel A: Changes in Federal Funding under a Uniform, Need-Based Block Grant

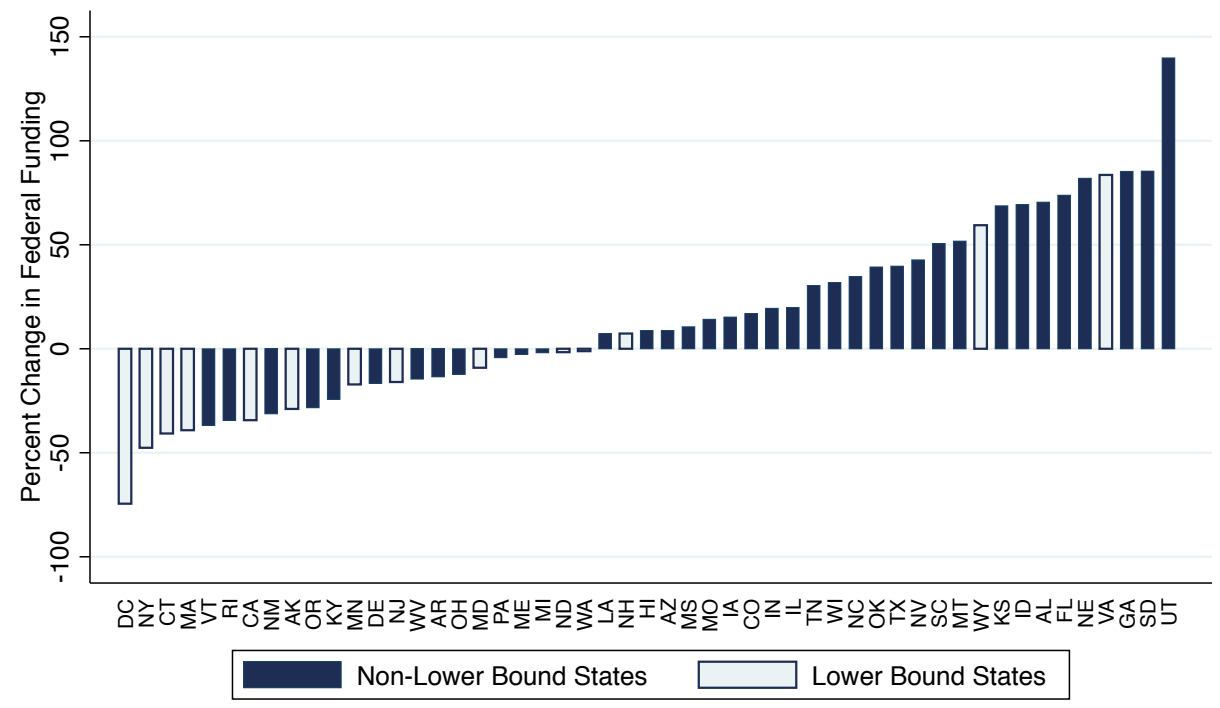

Panel B: Required Change in State Own-Source Revenue to Maintain Constant Total Spending

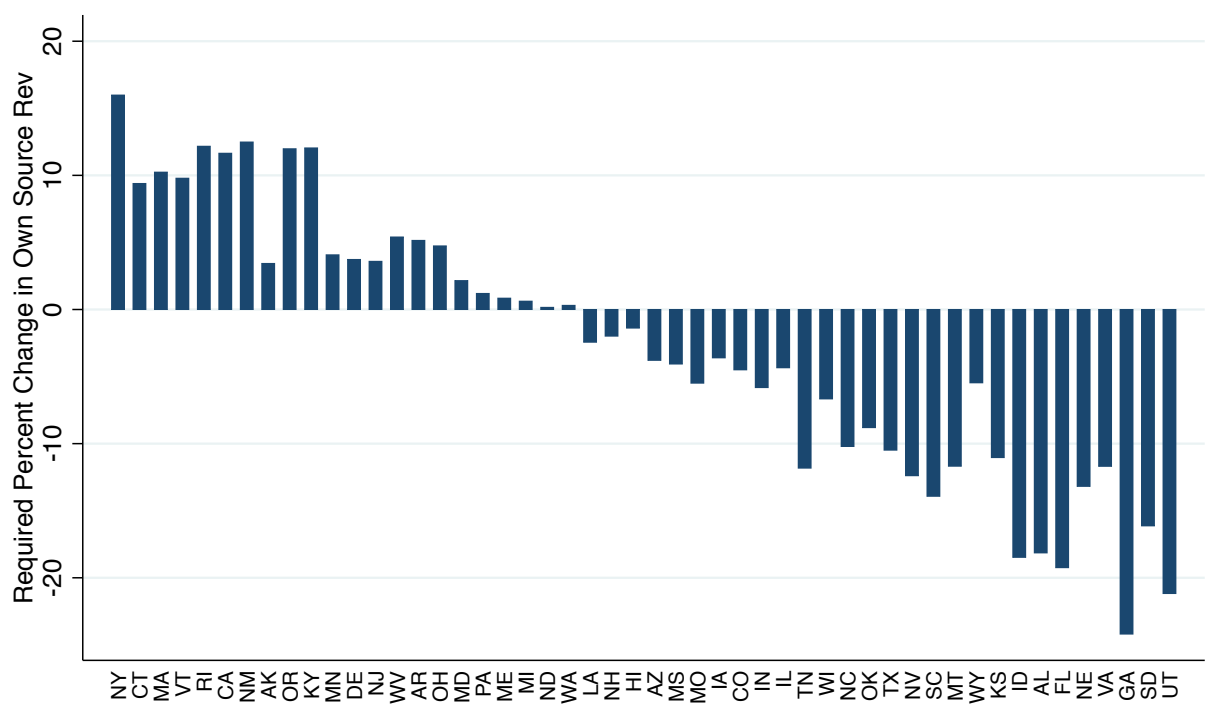

Figure 5: Changes in Federal and State Medicaid Funding under a Uniform, NeedBased Block Grant: This figure illustrates funding changes under a uniform, need-based block grant, relative to the current funding structure. Panel A shows the percentage change in federal funding for each state under the block grant relative to its allocation under the current financing system. Panel B shows the absolute change in federal funding as a percentage of each state's own-source revenue. State block grants are determined according to equation (3). Data on states' own-source revenue are taken from the 2014 Annual Survey of State and Local Government Finances. 
Changes in Federal Funding under a Uniform, Need-Based Block Grant

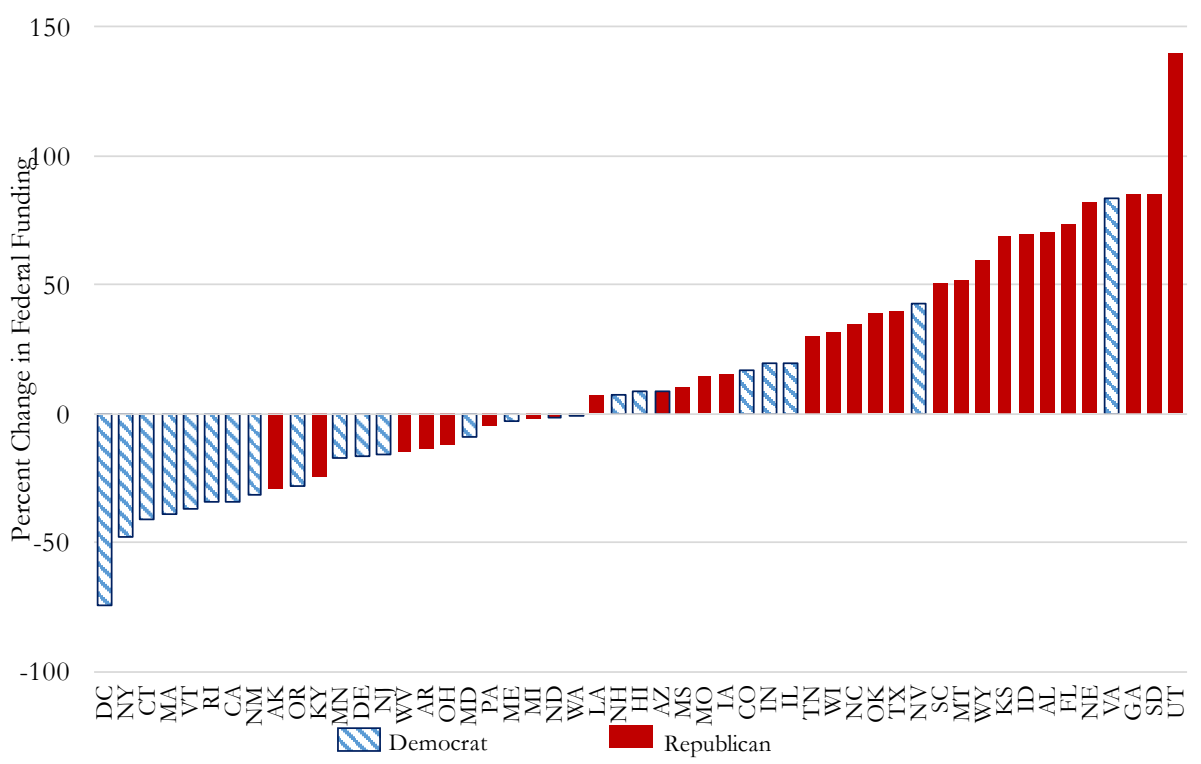

Figure 6: Changes in Federal Funding under a Uniform, Need-Based Block Grant: This figure illustrates funding changes under a uniform, need-based block grant, relative to current federal funding. Bars are shaded based on each state's vote in the 2016 presidential election, with solid and patterned fills corresponding to Republican and Democrat voting states, respectively. State block grants are estimated according to equation (3). 


\section{Federal Funding under Transitions to a Uniform, Need-Based Block Grant}

\section{Panel A: Aggregate Federal Funding}

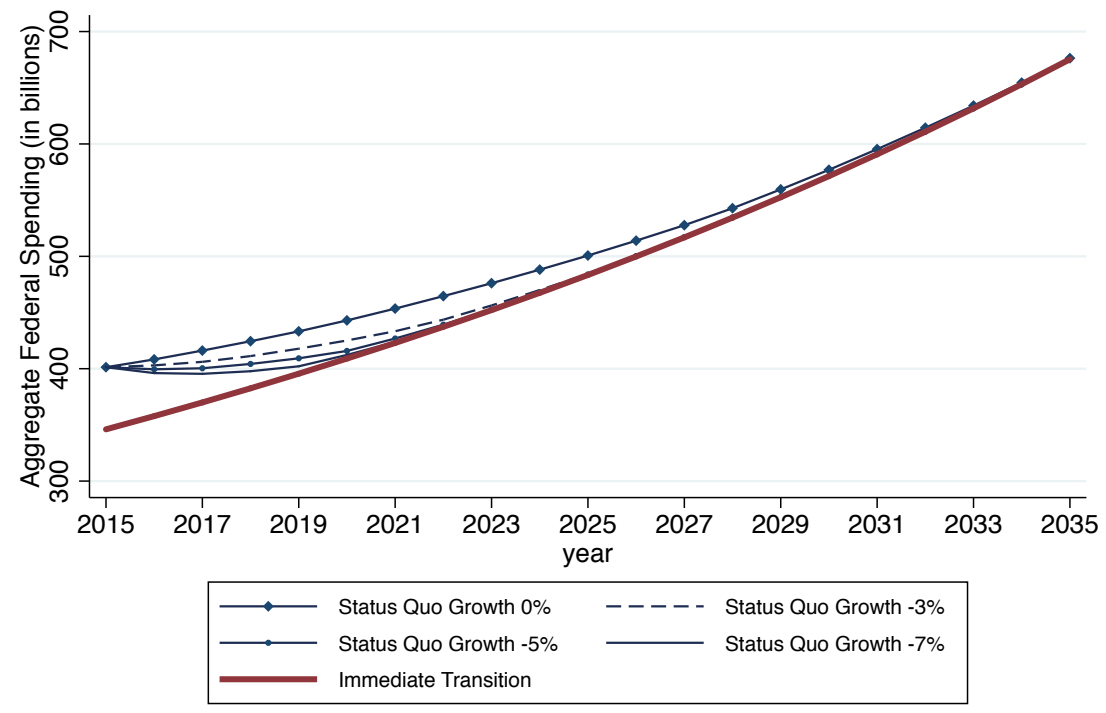

Panel B: Excess Federal Funding Relative to Immediate Transition

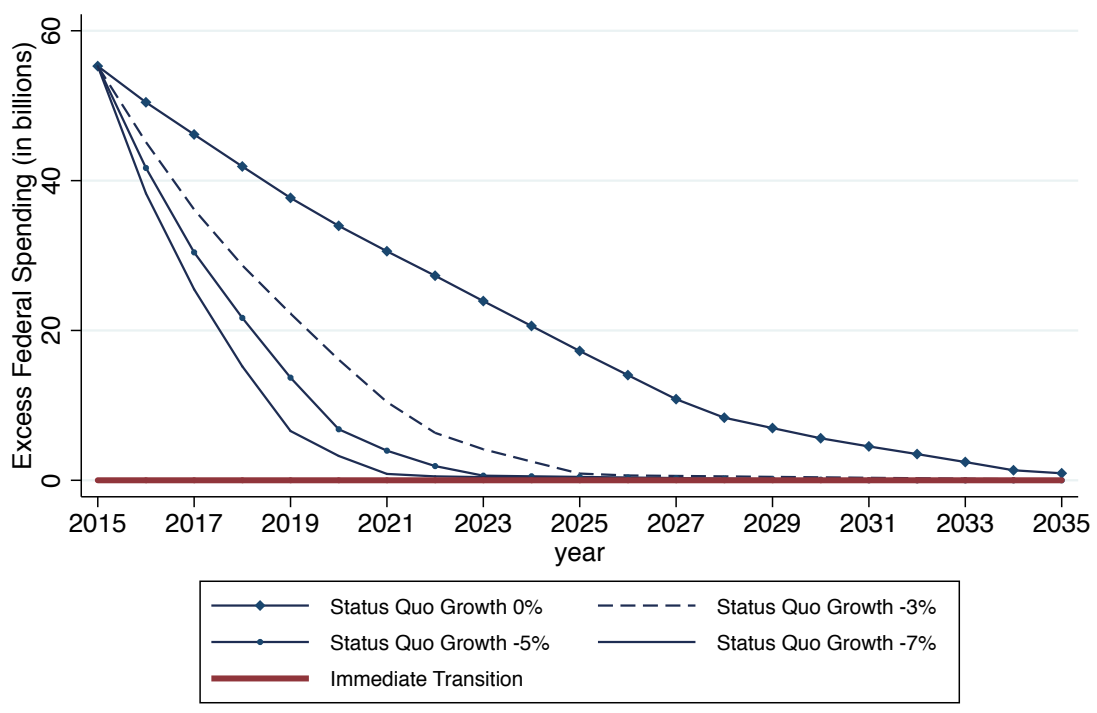

Figure 7: Federal Funding under Transitions to a Uniform, Need-Based Block Grant: This figure illustrates federal spending associated with alternative rules for transitioning from statusquo allocations to uniform, need-based block grants as described in section 3.6. Panel A illustrates aggregate federal funding under each scenario, while panel B shows the difference between federal funding with an immediate transition, which is revenue neutral by construction. Under each transition rule, states are offered the choice between the uniform, need-based block or a status-quo block. All transition rules assume that the uniform, need-based block grows at rate $g_{0}=3.4 \%$, which is the CBO estimate for long-run growth of per beneficiary Medicaid costs. Transition alternatives differ in the choice of $g_{1}$ - the rate of growth of the status-quo allotment. 
Federal and State Medicaid Funding under Acyclical Block Grants and Alternative Growth Rates

\section{Panel A: Federal Funding}

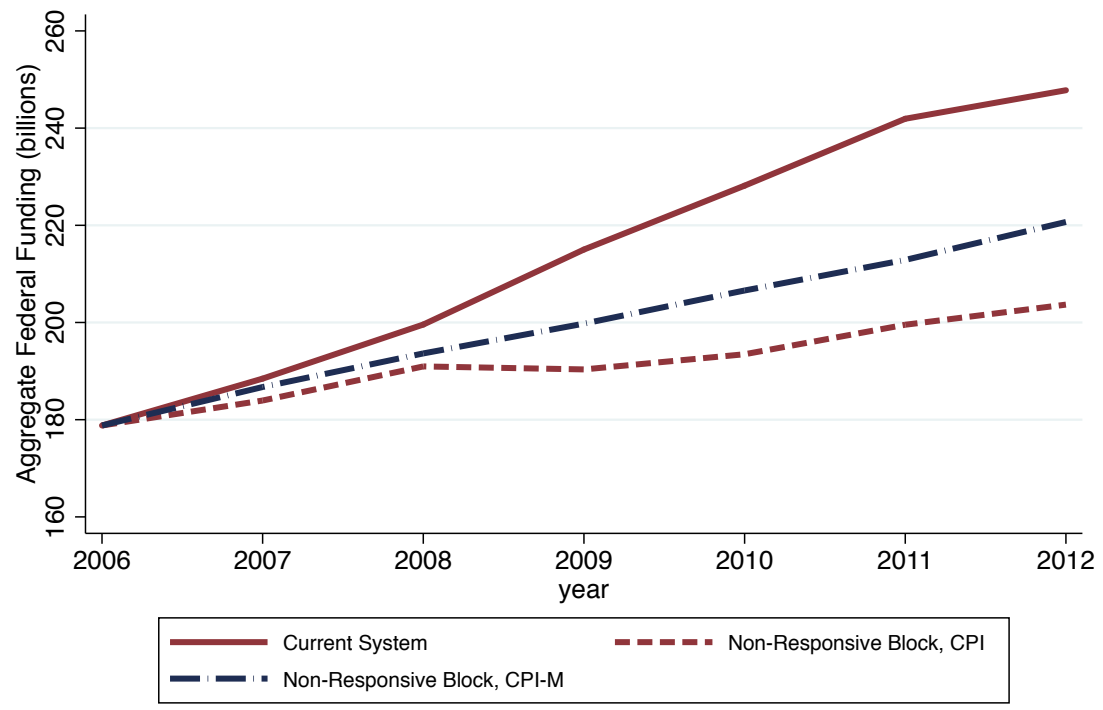

Panel B: State Funding Required for No Change in Total Spending

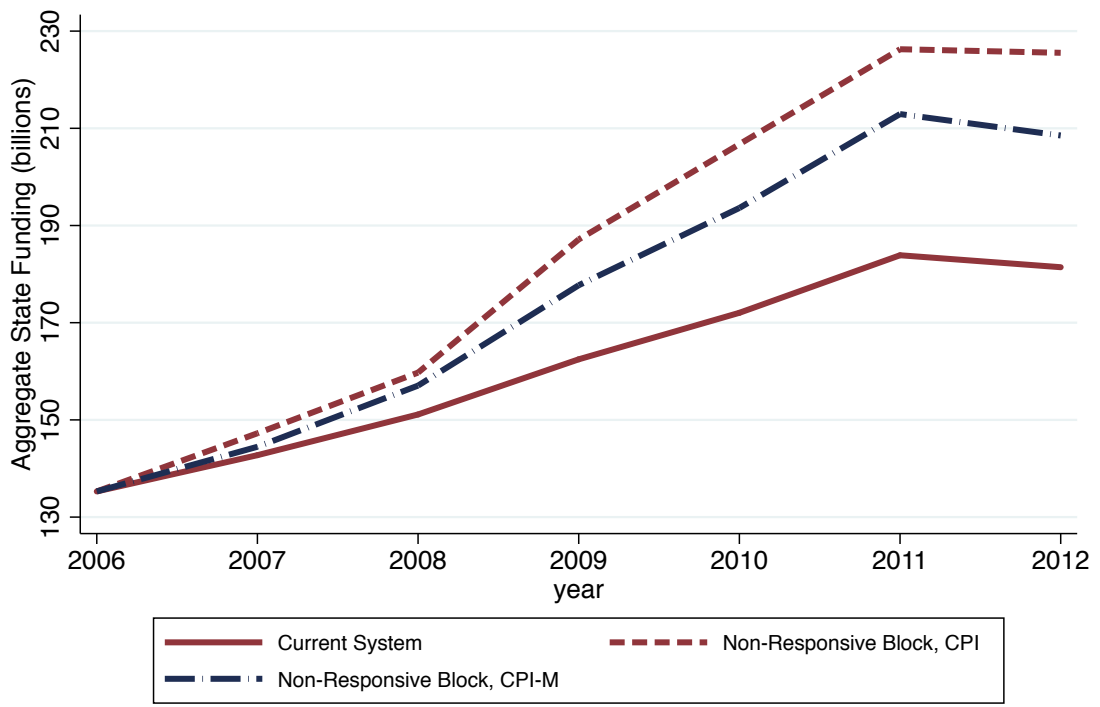

Figure 8: Federal Medicaid Funding under Acyclical Block Grants and Alternative Growth Rates: This figure illustrates federal funding from 2006 to 2012 under the current system (solid lines) relative to two acyclical block grants. The block grants are determined according to equation (1), with the base year corresponding with fiscal year 2006. For one of the block grants, the growth rate is set equal to the consumer price index for all urban consumers (CPI-U), while for the other it is set equal to the consumer price index for medical care services (CPI-M). 
Increased Cyclical Gaps as Shares of Own-Source Revenue

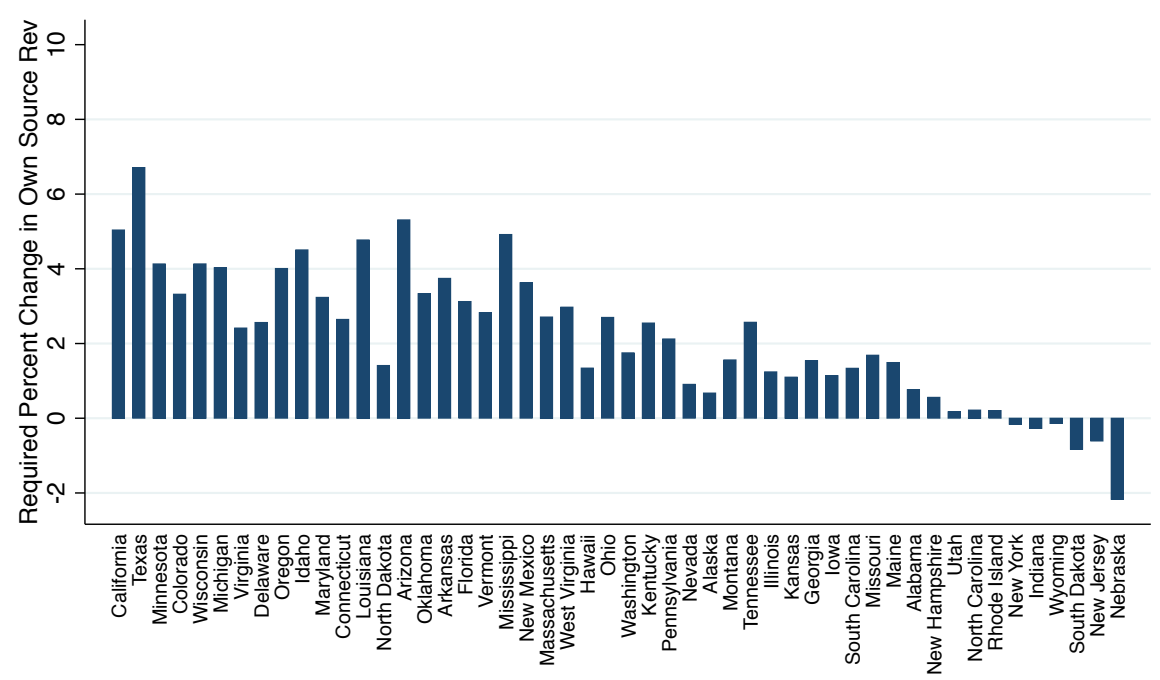

Figure 9: Increased Cyclical Gaps as Shares of Own-Source Revenue: This figure shows the percentage change in own-source revenue required for each state to cover the estimated shortfall of federal funding under an acyclical block grant relative to the current system in 2011. State block grants are determined according to equation (3), with the base year corresponding with fiscal year 2006. The growth rate is set equal to the consumer price index for medical care services (CPI-M). Own-source revenue is taken from the 2011 Annual Survey of State and Local Government Finances. 
Aggregate State and Federal Funding under Medicaid Funding Alternatives

\section{Panel A: Federal Funding}

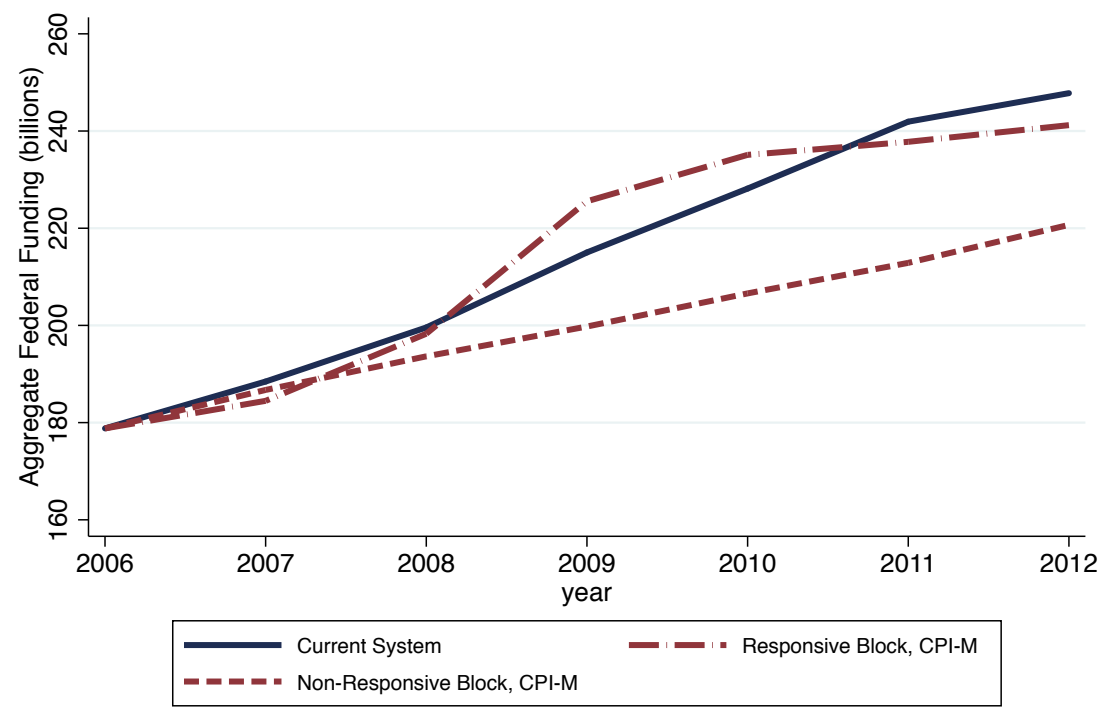

Panel B: State Funding Required for No Change in Total Spending

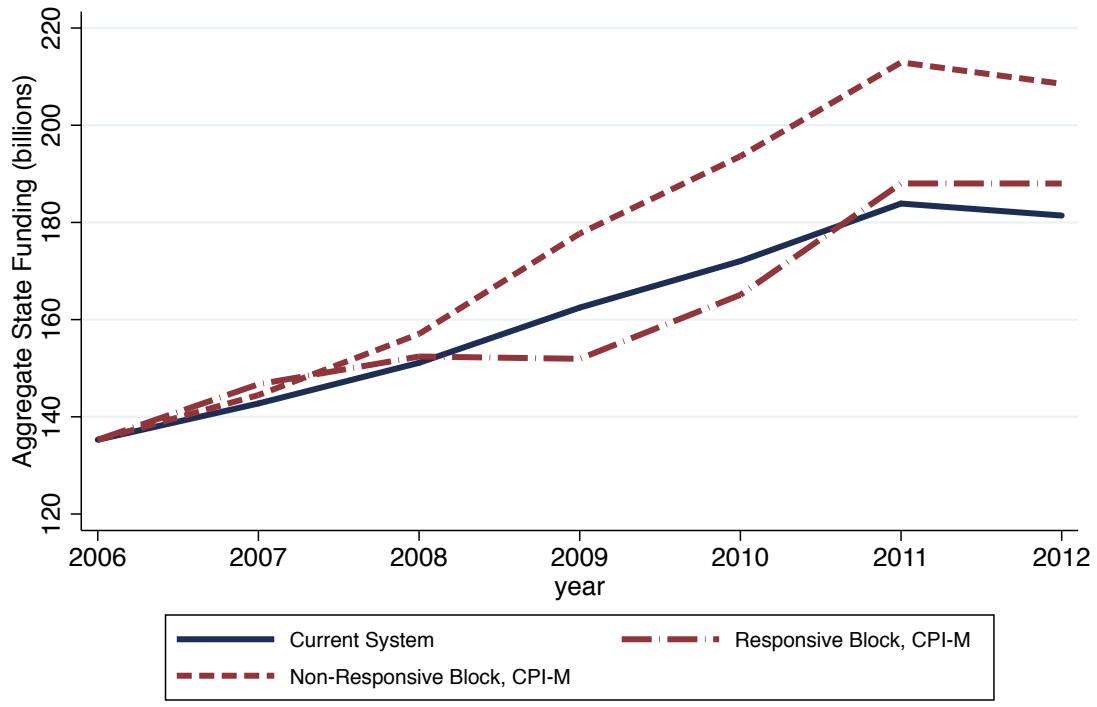

Figure 10: Aggregate State and Federal Funding under Medicaid Funding Alternatives: This figure illustrates estimated state and federal funding under alternative funding systems for 2006-12. Federal funding for the acyclical block and countercyclical block are based on equations (1) and (6), respectively. State funding is set equal to actual Medicaid spending minus the federal contribution. That is, we illustrate the amount of state funding that would have been required to finance the amount of Medicaid spending that occurred under the existing financing system. 
Federal Subsidization of New Enrollee Coverage: Long-Term Projections

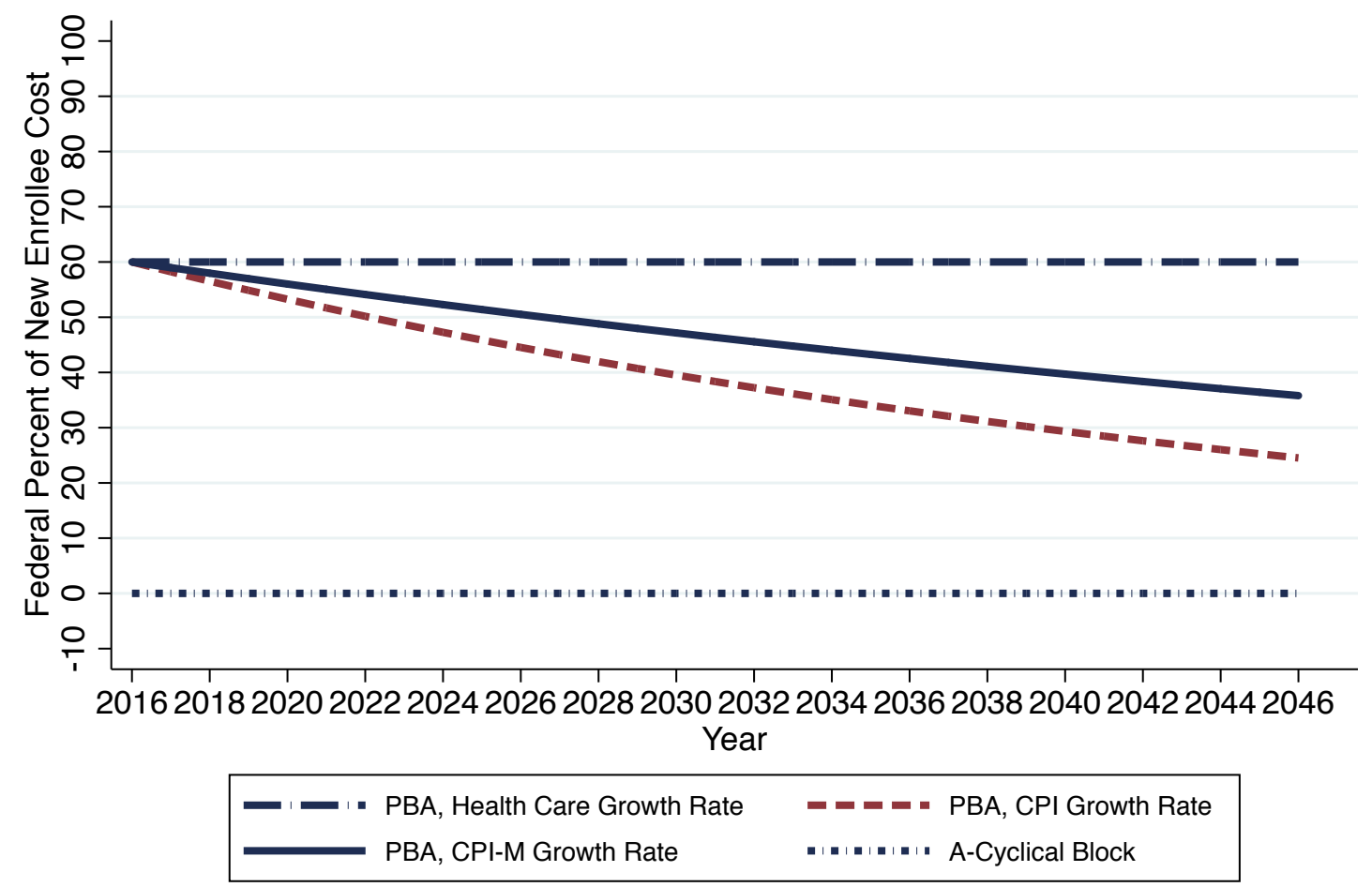

Figure 11: Federal Subsidization of New Enrollee Coverage: Long-Term Projections: This figure illustrates the evolution of the rates at which federal contributions subsidize the coverage of new enrollees under alternative financing structures. 
Table 1: Correlates of Differences in Federal Allocations between Status Quo Block Grants and Uniform, Need-Based Block Grants

\begin{tabular}{lcccc}
\hline & $(1)$ & $(2)$ & $(3)$ & $(4)$ \\
& \multicolumn{3}{c}{ Change Fed Funding Per Capita } \\
\hline Per Capita Income (in 1000s) & $-32.194^{* *}$ & & $-12.940+$ \\
& $(10.945)$ & & $(7.009)$ \\
Expansion State & & $-585.181^{* * *}$ & & $-343.424^{* *}$ \\
& & $(98.948)$ & & $(114.949)$ \\
Clinton Vote Share & & & $-26.187^{* * *}$ & $-14.097^{*}$ \\
& & & $(6.433)$ & $(6.919)$ \\
\hline R-Squared & & & 0.45 & 0.59 \\
$N$ & 51 & 51 & 51 & 51 \\
\hline
\end{tabular}

Note: $+,^{*}, * *$, and ${ }^{* * *}$ indicate statistical significance at the $0.10,0.05,0.01$, and 0.001 levels respectively. This table presents estimates of equation (5). The dependent variable is the difference in the size of states' federal Medicaid contributions under the uniform, need-based grant structure relative to the status quo. Note that states that enacted ACA Medicaid expansions in September of 2015 or later-Alaska, Louisiana, and Montana-do not have ACA expansion spending in our data for fiscal year 2015. Standard errors are robust to heteroskedasticity. 